\title{
Crustacean "cave fishes" from the Arabika karst massif (Abkhazia, Western Caucasus): new species of stygobiotic crustacean genera Xiphocaridinella and Niphargus from the Gegskaya Cave and adjacent area
}

\author{
«Пещерные рыбы» карстового массива Арабика (Абхазия, \\ Западный Кавказ): новые виды стигобионтных ракообразных \\ родов Xiphocaridinella и Niphargus из Гегской пешеры \\ и примегающих районов
}

\author{
Ivan N. Marin \\ Иван Н. Марин
}

\begin{abstract}
A.N. Severtzov Institute of Ecology and Evolution of RAS, Leninsky prosp., 33, Moscow 119071 Russia. E-mail: coralliodecapoda@mail.ru, vanomarin@yahoo.com

Biological Department, Altai State University, prospekt Lenina, 61, Barnaul, 656049 Russia.

Институт проблем экологии и эволюции им. А.Н. Северцова РАН, Ленинский просп., 33, Москва 119071 Россия.

Биологический факультет, Алтайский государственный университет, пр-т Ленина, 61, Барнаул 656049 Россия.
\end{abstract}

KEY WORDS: Crustacea, Malacostraca, Xiphocaridinella, Atyidae, Niphargus, Nipharidae, stygobiotic, new species, Gegskaya Cave, Arabika, Abkhazia, Caucasus.

КЛЮЧЕВЫЕ СЛОВА: Crustacea, Malacostraca, Xiphocaridinella, Atyidae, Niphargus, Nipharidae, стигобионты, новые виды, Гегская пещера, Арабика, Абхазия, Кавказ.

ABSTRACT. Stygobiotic animals washed from various groundwater sources from the Arabika karst massif (Abkhazia, Western Caucasus) were studied. As a result, new species of stygobiotic crustacean genera Xiphocaridinella and Niphargus were described based on DNA (COI mtDNA gene marker) and morphological studies in the Gegskaya (Gega) Cave. These crustaceans are probably the legendary cave-dwelling "fishes" which were previously reported from the Arabika karst massif. At the same time, during the study, no real cave fish or any evidence of their presence was found. Genetic delimitation thresholds for Caucasian Niphargus species are also discussed in the paper.

How to cite this article: Marin I.N. 2019. Crustacean "cave fishes" from the Arabika karst massif (Abkhazia, Western Caucasus): new species of stygobiotic crustacean genera Xiphocaridinella and Niphargus from the Gegskaya Cave and adjacent area // Arthropoda Selecta. Vol.28. No.2. P.225-245. doi: 10.15298/arthsel. 28.2.05

РЕЗЮМЕ. В работе представлены описания стигобионтных животных, вымытых из различных подземных источников разгрузки карстового массива Арабика (Абхазия, Западный Кавказ). На основе анализа ДНК и исследования морфологии из Гегской пещеры описаны новые виды стигобионтных ракообразных родов Xiphocaridinella и Niphargus. Эти ракообразные, вероятно, представляют собой легендарных «пещерных» рыбок, которых ранее видели в подземных озерах карстового массива Арабика. В то же время в ходе исследования не было обнаружено ни одной истинной пещерной рыбы или какого-либо подтверждения их присутствия. В статье также впервые обсуждаются пороги (thresholds) генетического разделения видов для кавказских видов рода Niphargus.

\section{Introduction}

Cave fishes are very diverse, being an important component of almost all tropical subterranean environments (e.g. Jeffery, 2001; Romero, 2001; Romero, Paulson, 2001; Culver, Pipan, 2009; Borowsky, 2018). Troglocobitis starostini (Parin, 1983) (Nemacheilidae), the only true cave-dwelling fish species presently known within the former USSR, including Europe and Central Asia, was described from the Köýtendag ridge $\left(37^{\circ} 55^{\prime} \mathrm{N}\right.$ $66^{\circ} 23^{\prime} \mathrm{E}$ ), Chardzhou province, Turkmenistan [Parin, 1983]. The only known European stygobiotic fish is presented by the underground population of the loach genus Barbatula Linck, 1790 (Nemacheilidae), recently discovered in the Donau-Aach underground karst water system in the southern Germany [BehrmannGodel et al., 2017] (provisionally named European cave loach). The population is morphologically and genetically differentiated from the common loach Barbatula barbatula (Linnaeus, 1758), living in the adja- 

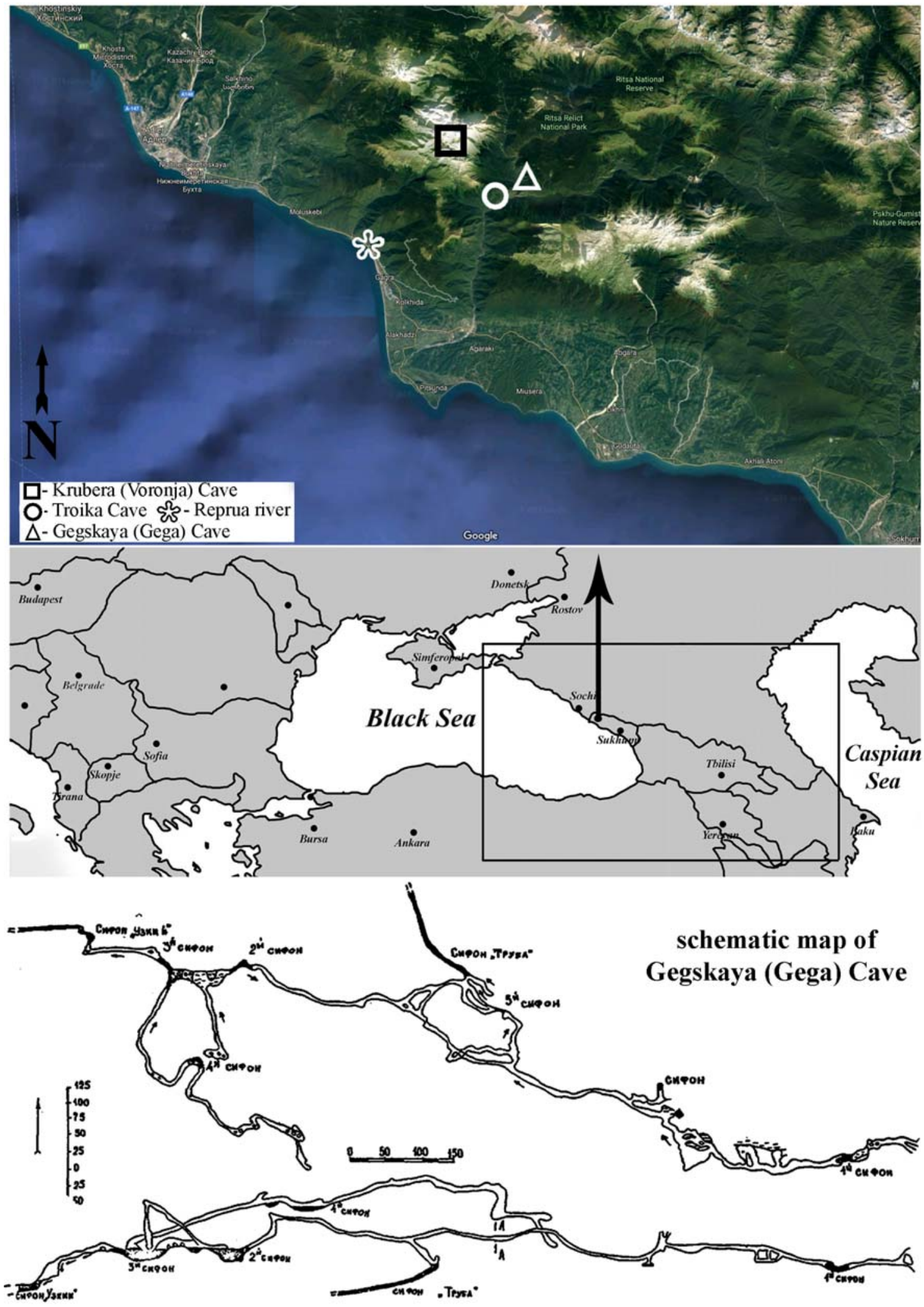

Fig. 1. Map of distribution of caves and rivers of the Arabika karst massif (Abkhazia, Western Caucasus) where crustaceans where collected; with schematic map of the Gegskaya (Gega) Cave.

Рис. 1. Карта размещения пещер и источников карстового массива Арабика (Абхазия, Западный Кавказ), где были собраны ракообразные; со схематической картой Гегской пещеры. 
cent surface waters, but not in the status of the separate species. To date, neither cave fish nor underground populations of common species have been described in karst systems in the Western Caucasus [Romero, Paulson, 2001], which is the second (after the Balkan Peninsula) region of the Western Palearctic in the size and diversity of karst landscapes.

At the same time, information about the possible occurrence of blind and translucent cave fishes inside the Arabika karst massif, namely inside the deepest world cave - Krubera (Voronya) Cave [Samokhin, Bizóukin, 2018] and Diaklaz siphon in Gegskaya (Gega) Cave [Anonymous, 2018]. was noticed by cave divers and published for several times on the Internet. Gennady Samokhin, a famous cave diver, noted after the diving in the "Two Captains" sump (-2144 m) inside the Krubera-Voronya Cave in August 2016 Expedition: "... lying in the crack, I observed a school of small, translucent fish with flat elongated bodies and tail fins. Why I haven't seen them before? Most likely, I focused on the morphology of the sump and did not notice them ..." [Samokhin, Bizyukin, 2018]. There is a legend that any "small transparent" fishes live in underground lakes inside caves of the Arabika karst massif. Unfortunately, scientists have never collected or researched samples of such mysterious Caucasian cave fishes. At the same time, it is known that a unique endemic fauna lives in the Arabika karst massif [e.g., Sidorov, 2014; Sidorov et al., 2015, 2018; Sidorov, Samokhin, 2016] and some interesting animals are expected to be discovered from there.

The hydrogeology of the groundwater flow in the Arabica karst massif with the highest point of the Arabica mountain $\left(43^{\circ} 25^{\prime} 06.3^{\prime \prime} \mathrm{N} 40^{\circ} 21^{\prime} 23.5^{\prime \prime} \mathrm{E}\right)$, located on the Gagra Range of the Western Caucasus, is represented by several springs (rivers), such as Reprua (river), Kholodnaya Rechka (Cold River), the Gega waterfall and the Gegskaya (Gega) Cave in the Bzyb Canyon, springs in the Goluboe (Blue) Lake as well as several small sources around the Gagra City (e.g., Kiknadze, 1979; Klimchuk, 1990, 2006). The author collected material from various sources of karst water discharge from the massif, and also took samples in some underground environments, including large underground lakes. As a result, numerous specimens of Xiphocaridinella and Niphargus were found in the studied springs and lakes, probably representing these legendary small transparent cave "fish" (see Fig. $2 a, b$ ), and the author photographed them in situ in a large subterranean lake inside the Gegskaya Cave $\left(43^{\circ} 23^{\prime}\right.$ $\left.43.7^{\prime \prime} \mathrm{N} 40^{\circ} 27^{\prime} 28.4^{\prime \prime} \mathrm{E}\right)$. A study of DNA markers and morphology of both collected Xiphocaridinella and Niphargus samples showed that they belong to distinct species described herewith as new to science. At the same time, during the study, no real cave fish were found. However, in situ photographs of representatives of the genus Xiphocaridinella showed a clear resemblance to blind and transparent swimming fishes (see Fig. 2b).

\section{Material and methods}

Specimens of Xiphocaridinella were collected by hand net from the Gegskaya (Gega) Cave $\left(43^{\circ} 23^{\prime} 43.7^{\prime \prime} \mathrm{N} 40^{\circ} 27^{\prime}\right.$ $\left.28.4^{\prime \prime} \mathrm{E}\right)$ and the Verevkina Cave $\left(43^{\circ} 24^{\prime} 56.0^{\prime \prime} \mathrm{N} 40^{\circ} 21^{\prime}\right.$ 23.0"E) while Niphargus specimens - from the Gegskaya (Gega) Cave and Reprua River $\left(43^{\circ} 19^{\prime} 52.0^{\prime \prime} \mathrm{N} 40^{\circ} 12^{\prime} 16.8^{\prime \prime} \mathrm{E}\right.$; $0 \mathrm{~m}$ above sea level) (see Fig. 1). Alive specimens of Xiphocaridinella and Niphargus were photographed in situ using Pentax digital camera. In addition, in the laboratory, live specimens of Xiphocaridinella and Niphargus were relaxed with clove oil and photographed using a Canon G16 camera. All collected specimens were preserved and stored in $96 \%$ solution of ethanol for further DNA analysis. Postorbital carapace length (pcl., in $\mathrm{mm}$ ), the length from posterior orbit to the posterodorsal margin of carapace, and total body length (tbl., in $\mathrm{mm}$ ), dorsal length from tip of rostrum till the distal margin of telson for Xiphocaridinella shrimps and dorsal length from the distal margin of head to the distal margin of telson (tbl., in $\mathrm{mm}$ ) for Niphargus, are used as standard measurements. Type material is deposited in the collection of the Zoological Museum of Moscow State University, Moscow (ZMMU), and additional material is in the collection of the Zoological Institute of the Russian Academy of Sciences (ZIN), St-Petersburg, Russia and the Laboratory of Ecology and Evolution of Marine Invertebrates (LEMMI) of A.N. Severtzov Institute of Ecology and Evolution of the Russian Academy of Sciences, Moscow, Russia.

To study molecular genetic barcode, a fragment of the mitochondrial gene coding for cytochrome $\mathrm{c}$ oxidase subunit I (COI mtDNA) gene marker was amplified, sequencing and compared. Total genomic DNA was extracted from abdominal and pereiopod muscle tissue using the innuPREP DNA Micro Kit (AnalitikJena, Germany) following the manufacturer's protocol. The gene marker was amplified with the help of the universal primers LCO1490 (5'-ggtcaacaaatcataaagatattgg-3') and HC02198 (5'-taaacttcagggtgaccaaaaaatca-3') [Folmer et al. 1994]. PCR products were performed on amplificator T100 (Bio-Rad, USA) under the following conditions: initial denaturation at $96^{\circ} \mathrm{C}$ for $1.5 \mathrm{~min}$ followed by 42 cycles of $95^{\circ} \mathrm{C}$ for $2 \mathrm{~min}, 49^{\circ} \mathrm{C}$ for 35 seconds, and $72^{\circ} \mathrm{C}$ for $1.5 \mathrm{~min}$, followed by chain extension at $72^{\circ} \mathrm{C}$ for 7 min. The volume of $10 \mathrm{uL}$ of reaction mixture contained $1 \mathrm{uL}$ of total DNA, $2 \mathrm{uL}$ of 5xPCR mix (Dialat, Russia) and $1 \mathrm{uL}$ of each primer. The amplification products were separated by using gel electrophoresis of nucleic acids on a $1.5 \%$ agarose gel in 1xTBE, and then stained and visualized with $0.003 \%$ EtBr using imaging UV software. DNA nucleotide sequences were determined using Genetic Analyzer ABI 3500 (Applied Biosystems Inc.) and BigDye 3.1 (Applied Biosystems Inc.) with direct and reverse primers. Uniformity of obtained sequences was processed using the program BioEdit v. 5.0.9. A dataset of COI mtDNA gene markers used in the study are presented in previously published data on Xiphocaridinella (see Marin, 2018a, b) as well as were taken from GenBank (NCBI) (see Appendix 1). The aligned sequences of COI mtDNA gene markers, 658 base pairs in length, were analyzed for pairwise sequence divergence (uncorrected $p$-distances) and used to construct the phylogenetic relations. The best evolutionary substitution model was determined using MEGA 7.0. and jModeltest2.1.141. Phylogenetic analysis was performed using MrBayes v.32.6 for Bayesian analysis (BA) using NKY $+\mathrm{I}+\mathrm{G}$ evolutionary model and MEGA 7.0 for Maximum-Likelihood (ML), Neighbour-Joining (NJ), UPGMA (unweighted pair group method 
with arithmetic mean) analyses using Kimura-2-parameter (K2P) model. Bayesian analysis was carried out by sampling one tree every 1,000 generations over $1,000,000$ generations. Values of confidence $>50 \%$ are presented for ML, NJ and BA analyses (bootstraps); the divergence of pairwise genetic distances (p-distances) was calculated using the Kimura-2-parameter (K2P) model in MEGA 7.0. The species delimitation is carried out according to the latest understanding of the interspecific distances at cave crustaceans [Zakšek et al., 2009, 2019; Copilas-Ciocianu et al., 2017; Deliæ et al., 2017; Marin, 2017b, 2018a, b].

\section{Systematic account}

\author{
Order Decapoda Latreille, 1802 \\ Family Atyidae De Haan, 1849 \\ Genus Xiphocaridinella Sadowsky, 1930 \\ Xiphocaridinella dbari sp.n.
}

Figs. 2-5.

MATERIAL EXAMINED. Holotype: 1 male (pcl. $7.5 \mathrm{~mm}$, tbl. $24.0 \mathrm{~mm}$ ), ZMMU Ma3574, Abkhazia, Gagry region, Bzyb River Canyon, Gegskaya (Gega) Cave, 43⒉ $3^{\prime} 43.7^{\prime \prime} \mathrm{N} 40^{\circ} 27^{\prime} 28.4^{\prime \prime} \mathrm{E}$, about $273 \mathrm{~m}$ above sea level, in cave lake, coll. I. Marin, 17 Sept. 2017; 5 non-ovigerous females, 5 males, (LEMMI), same locality and date as holotype; 1 non-ovigerous females, LEMMI, Abkhazia, Gagry region, Arabika karst massif, Verevkina Cave, $43^{\circ} 24^{\prime} 56.0^{\prime \prime} \mathrm{N} 40^{\circ} 21^{\prime}$ $23.0^{\prime \prime} \mathrm{E}$, about $-400 \mathrm{~m}$ from of the cave entrance, in cave lake, unknown date, unknown collector; 1 non-ovigerous females, LEMMI, Verevkina Cave, coll. Natalia and Andrey Sizikov, 10-15 Sept. 2018.

DESCRIPTION. Medium-sized shrimp with swollen, smooth, subcylindrical body (Fig. 2e-g). Carapace swollen, smooth, with small dorsal carina in frontal part (Fig. $3 a-d$ ). Rostrum (Fig. $3 a-d$ ) short, robust, slender, not reaching the distal margin of basal antennular segment, triangular in shape, dorsally and ventrally unarmed, sharply pointed distally, with tip turned forward, broad proximally, with developed lateral lamina (Fig. $3 a-d$ ).

Abdominal somites smooth, unarmed; tergites non-carinate, without dorsal lobes, not posteriorly produced; pleura of pleomeres I-IV posteroventrally and ventrally rounded; pleomere V small, with feebly developed pleura; distal and distoventral margins of pleomere VI sharply produced posterodorsally. Telson (Fig. 3e) relatively slender, smooth, about 3 times as long as wide proximally, tapering distally, with 2 pairs of slender dorsal spines, each about 0.08 of telson length, situated at about 0.45 and 0.75 telson length respectively; distal margin convex, with 4-5 pairs of distal spines, including a pair of short lateral spines, a pair of long intermediate spines and 2-3 pairs of slender medial marginal spines.

Eyes (Fig. $3 a-d$ ) partly reduced, subcylindrical, covered by carapace; cornea rounded, reduced and feebly marked, without pigment; eyestalk stout, swollen, cylindrical, about as long as wide.

Antennula (Fig. $3 a-d, f$ ) with stout unarmed articles, basal peduncular segment robust, about twice as long as proximal width, without ventromedial tooth, distolateral angle with broadly produced blunt projection (Fig. 3f); stylocerite stout, sharpening distally, overreaching the midlength of basal segment; second and third segments stout, unarmed; second segment about 1.5-2 times as long as wide and about 1.5-2 times as long as distal segment; distal segment about as long as wide.
Antenna (Fig. $3 g$ ) with basicerite stout, about 1.5 times as wide as long, with distolateral margin unarmed; carpocerite robust, about 1.5 times as long as wide, not reaching midlength of scaphocerite; scaphocerite well developed, broad, with small but well marked distolateral tooth, lamella bluntly rounded distally.

Mouthparts typical for the genus and were not dissected. Maxilliped III (Fig. 4a) with slender segments; epipodite stout, bluntly rounded; arthrobranch reduced; exopodite slender, overreaching the distal margin of antepenultimate segment; antepenultimate segment slender, about 6-7 times as long as wide; penultimate segment about 6-7 times as long as wide, with straight lateral margins; ultimate (distal) segment slender, equal to penultimate segment, about 6-7 times as long as wide, tapering distally, with tufts of short simple stick-like setae along ventral and lateral margins, with several tufts of long setae dorsally.

Pereiopods I equal in size and similar in shape, and similar in females (Fig. 4b) and males (Fig. $4 g$ ), with smooth unarmed segments; coxa with well-developed slender epipodite and tuft of long simple setobranchs; basis about as long as wide, with well-developed exopodite overreaching carpo-meral articulation; ischium about 2-3 times longer than wide, with straight margins; merus slender, about 3 times as long as wide, equal to ischium, with straight margins; carpus relatively stout, significantly widening distally, equal to merus, about as 1.5 times as long as maximal width; palm relatively stout, about as long as wide, subcylindrical in cross-section, smooth; fingers relatively slender, subcylindrical, smooth, with blunt distal margins, about 3 times as long as proximal width, armed with a row of stout strong plumose setae distally.

Pereiopods II (Fig. $4 c, h$ ) equal in size and similar in shape, similar in males and females and almost similar to pereiopod I, with relatively stouter basal smooth unarmed segments; coxa with well-developed slender epipodite and tuft of setobranchs; basis about as long as wide, with welldeveloped exopodite overreaching carpo-meral articulation; ischium about 3 times as long as wide, with straight margins, unarmed; merus slender, about 4 times as long as wide, usually equal to ischium or lightly longer, with straight margins; carpus slender, about 4-5 times as long as wide, slightly widening distally, longer than merus; palm relatively stout, similar to palm of pereiopod I, about as long as wide, subcylindrical in cross-section, smooth; fingers relatively slender, subcylindrical, smooth tapering distally, about 4 times as long as proximal width, with simple and straight cutting edges, with broad blunt distal margin, armed with a row of stout strong plumose setae distally.

Pereiopod III in females (Fig. 4d) with rectangular coxa, about as long as wide, with tuft of long simple setobranchs, with small epipodite; basis about as long as wide, with wellmarked exopodite almost reaching the midlength of merus; ischium about 2 times as long as wide, with well-marked distoventral spine; merus about 7 times as long as wide, with straight margins, with 2 well marked spines along ventral margin; carpus relatively slender, about 6 times as long as wide, slightly widening distally, about $1.5-2$ times shorter than merus and slightly longer than half of the length of propodus, with bluntly projecting distodorsal margin overlapping carpo-propodal articulation; propodus about 10 times as long as wide, with straight margins, armed with 7-8 spines along proximal half of ventral margin (Fig. 4d); dactylus (Fig. $5 g$ ) about 3 times longer than wide, biunguiculate, ventral margin armed with 6-7 small spines, main 


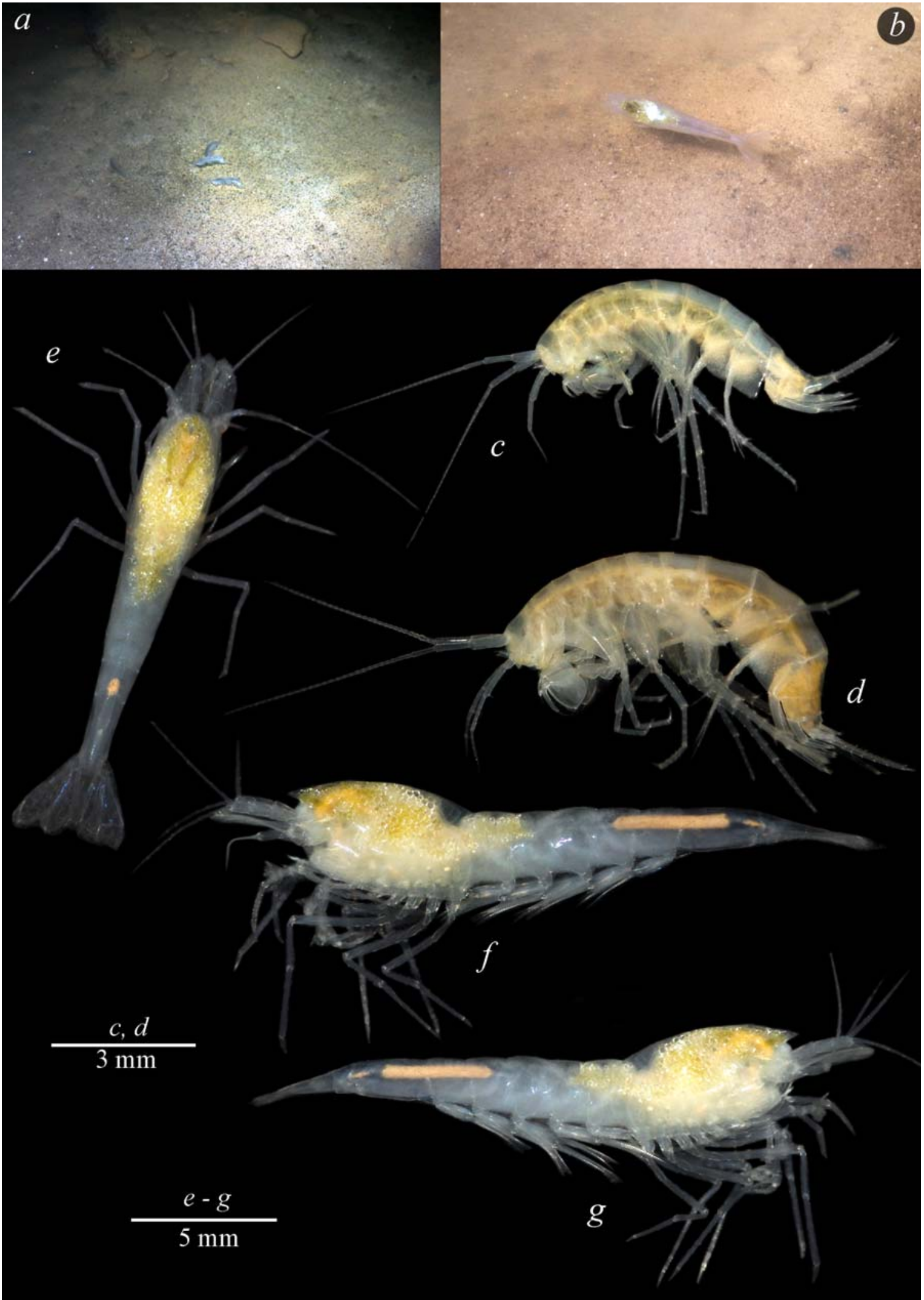

Fig. 2. Photo of Niphargus (a) and Xiphocaridinella $(b)$ in situ and alive coloration of Niphargus gegi sp.n. $(c, d)$ and Xiphocaridinella dbari sp.n. (e-g) from the Gegskaya (Gega) Cave, Arabika karst massif.

Рис. 2. Фотографии представителей рода Niphargus (a) и Xiphocaridinella (b) in situ и прижизненная окраска Niphargus gegi sp.n. $(c, d)$ и Xiphocaridinella dbari sp.n. $(e-g)$ из Гегской пещеры, карстовый массив Арабика. 


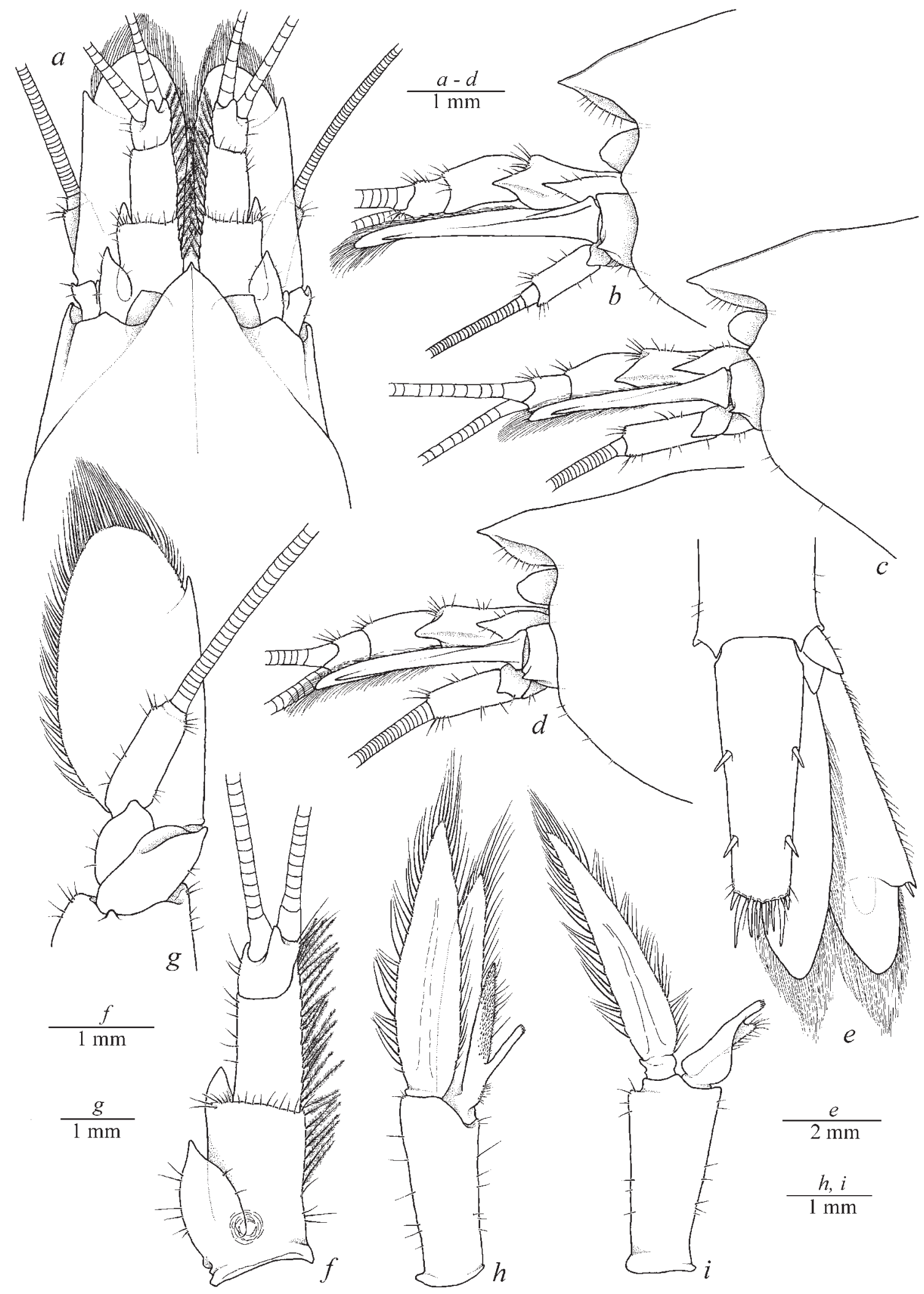

Fig. 3. Xiphocaridinella dbari sp.n., LEMMI, female $(a, d-g)$, male $(b, c, h, i)$, Gegskaya (Gega) Cave, Arabika karst massif: $a-$ front of carapace, dorsal view; $b-d$ - front of carapace, lateral view; $e$ - telson; $f$ - antennula; $g$ - antenna; $h$ - pleopod I; $i$ - pleopod II. Pис. 3. Xiphocaridinella dbari sp.n., LEMMI, самка $(a, d-g)$, самец $(b, c, h, i)$, Гегская пещера (Gega), карстовый массив Арабика: $a$ - передняя часть карапакса, вид сверху; $b-d-$ передняя часть карапакса, вид сбоку; $e$ - тельсон; $f$ - антенна; $g$ антенна; $h$ - плеопода I; $i$ - плеопод II. 


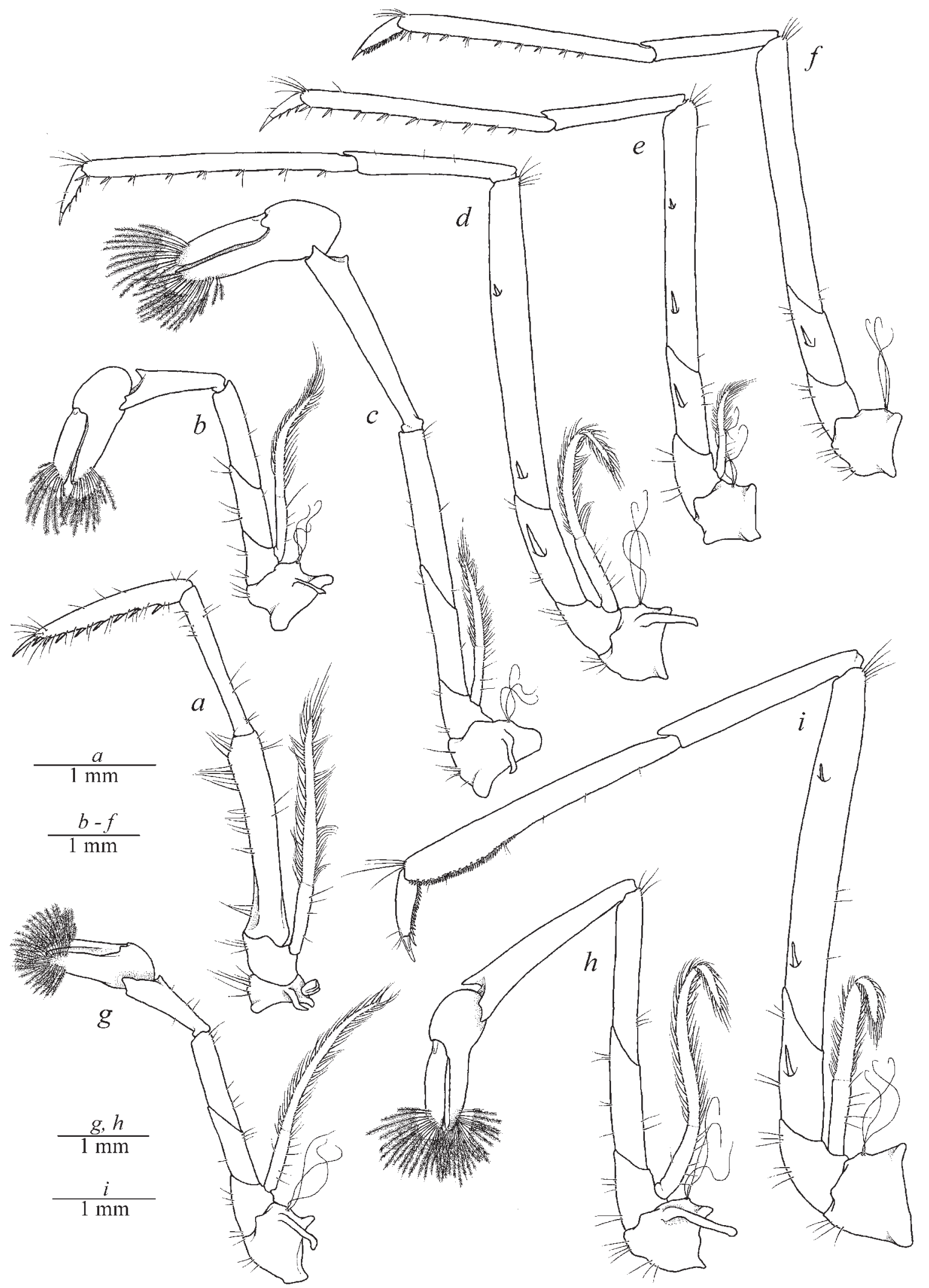

Fig. 4. Xiphocaridinella dbari sp.n., LEMMI, female $(a-f)$, male $(g-i)$, Gegskaya (Gega) Cave, Arabika karst massif: $a$ - maxilliped III; $b, g$ - pereiopod I; $c, h$ - pereiopod II; $d, i$ - pereiopod III; $e$ - pereiopod IV; $f$ - pereiopod V.

Рис. 4. Xiphocaridinella dbari sp.n., LEMMI, самка $(a-f)$, самец $(g-i)$, Гегская пещера, карстовый массив Арабика: $a-$ максиллипеда III; $b, g$ - переопода I; $c, h$ - переопода II; $d, i$ - переопода III; $e$ - переопода IV; $f$ - переопода V. 


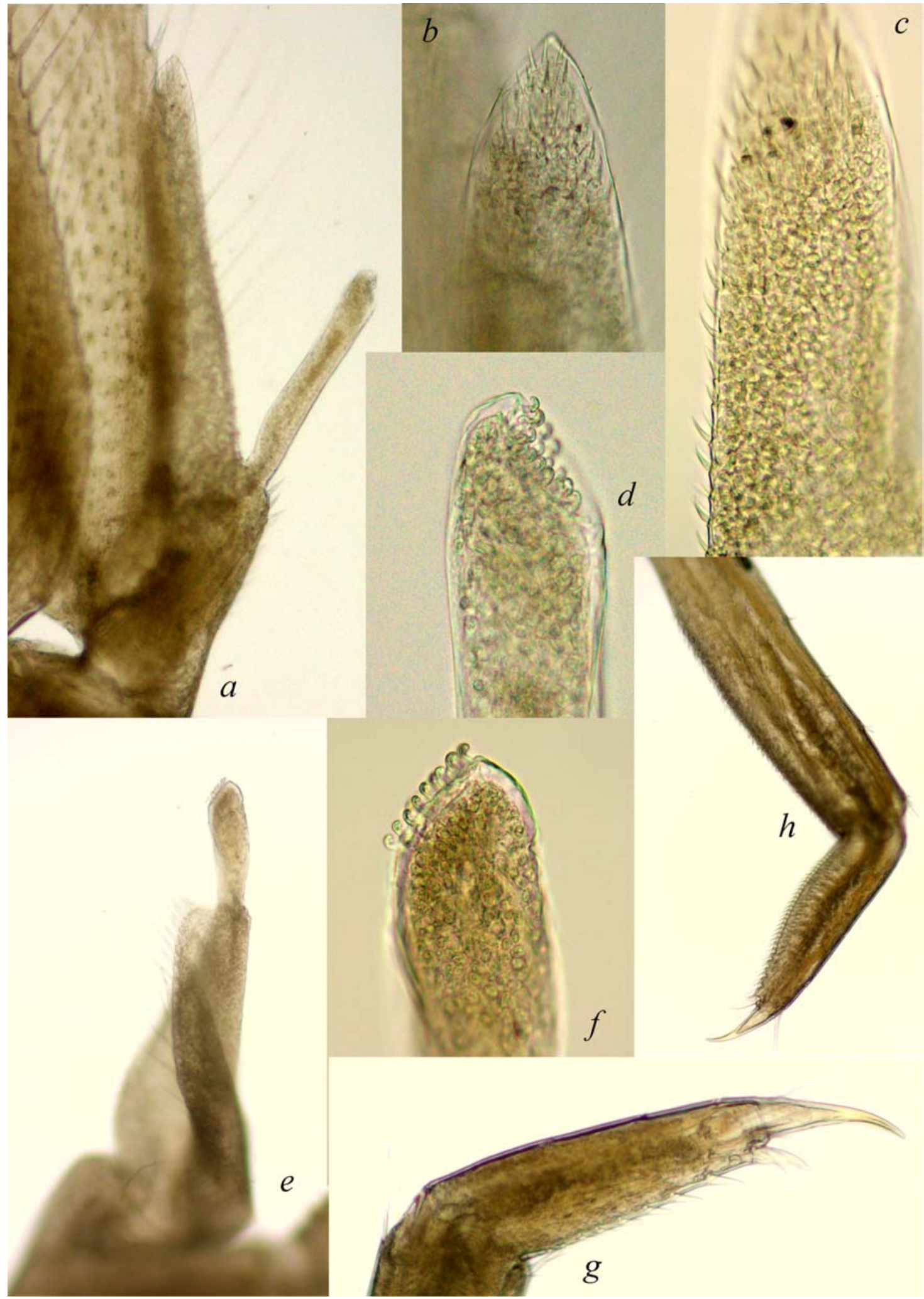

Fig. 5. Xiphocaridinella dbari sp.n., LEMMI, male $(a-f, h)$, female ( $g$ ), Gegskaya (Gega) Cave, Arabika karst massif: $a$ — pleopod I; $b$ - same, appendix interna, apical part; $c$ - same, appendix interna, distal part; $d$ - distal part of appendix masculina; $e$ - pleopod II; $f$ - distal part of appendix masculina; $g, h$ - dactylus of pereiopod III.

Pис. 5. Xiphocaridinella dbari sp.n., LEMMI, самец $(a-f, h)$, самка $(g)$, Гегская пещера, карстовый массив Арабика: $a-$ плеопод I; $b$ - то же, appendix interna, апикальная часть; с - то же, appendix interna, дистальная часть; $d$ - дистальная часть appendix masculina; $e$ - плеопод II; $f$ - дистальная часть appendix masculina; $g, h$ - дактилус переопода III. 
unguis smooth, curved and sharp; accessory unguis triangular, sharp, larger than ventral teeth, about twice shorter than main unguis. Pereiopod IV in females (Fig. 4e) generally similar to pereiopod III; merus armed with 2 spines, carpus without spine; exopodite smaller than in pereiopod III. Pereiopod $\mathrm{V}$ in females (Fig. 4f) generally similar to pereiopods III and IV, but without armature on basal segments and exopodite on basis; segments covered with simple setae dorsally and ventrally; propodus about $9-10$ times as long as wide, with straight margins, armed with $8-10$ long spines along ventral margin and pair of long slender spines at distoventral angle; dactylus with ventral margin armed with a dense "brush" consisting of small simple sharp setae; without accessory unguis, main unguis curved, triangular, sharp distally.

Morphological differences between males and females lead in the structure of distal part of propodi and dactyli of pereiopods III (Figs $4 d, i, 5 g, h$ ). Pereiopod III in males (Fig. $4 i$ ) with relatively slender segments; coxa rectangular, about as long as wide, with tuft of long simple setobranchs, with epipodite; basis about as long as wide, with wellmarked exopodite overreaching the distal margin of ischium; ischium about 1.5 times as long as wide, with wellmarked distoventral spine; merus about 6 times as long as wide, with straight margins, with 2 well marked spines along ventral margin; carpus relatively slender, about 5-6 times as long as wide, slightly widening distally, about twice shorter than merus and 1.5 times shorter than propodus, with bluntly projecting distodorsal margin slightly overlapping carpopropodal articulation, without subdistal spine; propodus about 8 times as long as wide, with straight margins, distal third of propodus widening and armed with a series of small spines along its ventral margin; dactylus (Fig. $5 h$ ) about 3 times as long as wide, with single unguis, ventral margin armed with small relatively stout sharp teeth, main unguis smooth, curved and sharp.

Pleopods I and II in females normal, characteristic for the genus without specific differentiating features. Pleopod I in males with endopod bearing well marked appendix inter$n a$ (Fig. 5e). Pleopod II in males (Fig. 5a) with well-developed appendix interna and appendix masculina (Fig. 5j); appendix interna with small cincinnuli distally (Fig. $5 d, f$ ); appendix masculina covered with numerous small sharp stout simple spines (Fig. $5 b, c$ ).
Uropods (Fig. 3e) relatively stout, remarkably exceeding telson; lateral margin of uropodal exopodite article 1 straight, with sharp triangular distolateral angle; dieresis simple, with 1 spine.

COLORATION. Body and appendages of shrimps transparent whitish and yellowish; cornea of eyes albescent; internal organs (gonads and hepatopancreas) whitish or yellowish; numerous small transparent fat granules can be seen through carapace (Fig. 2e-g).

BODY SIZE. The largest collected female has pcl. 7.5 $\mathrm{mm}$, tbl. $24.0 \mathrm{~mm}$; the largest collected male has pcl. 6.0 $\mathrm{mm}$, tbl. $20.0 \mathrm{~mm}$.

GENBANK ACCESSION NUMBER. MK875787.

DISTRIBUTION. The species is known from an underground lake inside the Gegskaya Cave, $43^{\circ} 23^{\prime} 43.7^{\prime \prime} \mathrm{N} 40^{\circ}$ $27^{\prime} 28.4^{\prime \prime}$ E, Abkhazia, Western Caucasus (the type locality) and from the Verevkina Cave $\left(43^{\circ} 24^{\prime} 56.0^{\prime \prime} \mathrm{N} 40^{\circ} 21^{\prime} 23.0^{\prime \prime} \mathrm{E}\right)$ at a depth $-2100 \mathrm{~m}$ (from the upper entrance), where a small population differing for $1 \%$ by COI mtDNA gene marker ( 0.01 substitutions per 100 nucleotide positions $(n=1))$ was found in 2017 and only a single female was collected and sequenced for this study (see Appendix 1). It can be assumed that the same species also live in the deep underground lakes of the neighboring Krubera-Voronya Cave $\left(43^{\circ} 24 " 35\right.$ ? N $40^{\circ} 21^{\prime \prime} 44$ ?E), where have already been reported about cave shrimp from water siphon at a depth $-2140 \mathrm{~m}$ [Sendra, Reboleira, 2012] but shrimp specimens from there were not available for our study.

ETYMOLOGY. The species is dedicated to Dr. Roman Saidovich Dbar, a famous Abkhazian zoologist, in recognition of his long-time studies on the diversity of the animal world of Abkhazia and a leading role in organization of biological research in this area of Caucasus. Roman Zbar is the head of the Institute of Ecology of the Academy of Sciences of Abkhazia, a member of the Government of the Republic of Abkhazia, and the chairman of the State Committee of the Republic of Abkhazia on ecology and environmental management.

TAXONOMIC REMARKS. The new species morphologically differs from the Caucasian congeners by relatively long and distally sharp, but unarmed rostrum. Rostrum features are relatively constant (Fig. $3 a-d$ ). Based on genetic barcoding data (see Table 1; Fig. 10), Xiphocaridinella jusbaschjani, known from the Agura river $\left(39^{\circ} 48^{\prime} 40.54^{\prime \prime} \mathrm{E} 43^{\circ}\right.$

Table 1. Pairwise interspecific genetic (COI mtDNA) distances ( $p$-distance \pm SE) between known Caucasian species of the genus Xiphocaridinella and Xiphocaridinella dbari sp.n. from the Gegskaya Cave $(\mathrm{n}=5)$.

Таблица 1. Попарные межвидовые генетические (COI мтДНК) дистанции ( $p$-distance $\pm \mathrm{SE}$ ) между известными кавказскими видами рода Xiphocaridinella и Xiphocaridinella dbari sp. nov. из Гегской пещеры (n=5).

Xiphocaridinella dbari sp.n. from Verevkina Cave $(\mathrm{n}=2)$

Xiphocaridinella fagei $(\mathrm{n}=3)$

Xiphocaridinella jusbaschjani $(\mathrm{n}=3)$

Xiphocaridinella kumistavi $(\mathrm{n}=9)$

Xiphocaridinella ablaskiri $(\mathrm{n}=5)$

Xiphocaridinella otapi $(\mathrm{n}=5)$

Xiphocaridinella shurubumu $(\mathrm{n}=5)$

Xiphocaridinella osterlofi $(\mathrm{n}=5)$

Xiphocaridinella kutaissiana $(\mathrm{n}=6)$
$0.012 \pm 0,004$

$0.062 \pm 0,010$

$0.068 \pm 0,011$

$0.107 \pm 0,014$

$0.112 \pm 0,015$

$0.113 \pm 0,015$

$0.115 \pm 0,015$

$0.121 \pm 0,015$

$0.122 \pm 0,016$ 
$32^{\prime} 57.26^{\prime \prime} \mathrm{N}$ ) in Sochi area of the Russian Federation, and Xiphocaridinella fagei, known from the Anatolia Lake inside the New Athos (Novo-Afonskaya) Cave $\left(43^{\circ} 5^{\prime} 44^{\prime \prime} \mathrm{N}\right.$ $\left.40^{\circ} 48^{\prime} 53^{\prime \prime} \mathrm{E}\right)$ in Abkhazia, are the most closely relative within Caucasian Xiphocaridinella. These species are also characterized by short unarmed rostrum, but can be morphologically distinguished from the new species as following. $X i-$ phocaridinella jusbaschjani clearly differs from the new species by shorter rostrum, slightly overreaching the distal margins of cornea of eye (see Marin, Sokolova, 2014: figs $2 a-c$ ), blunt stylocerite (see Marin, Sokolova, 2014: fig. $2 a$, $h$ ), the different position of dorsal spines on telson (see Marin, Sokolova, 2014: fig. $2 d, f$ ) and more robust ambulatory pereiopods, especially pereiopods II and III (see Marin, Sokolova, 2014: fig. 4b, $c, d$ ). At the same time, Xiphocaridinella fagei can be separated from Xiphocaridinella dbari mostly by long and distally pointed unarmed rostrum, reaching the distal margin of basal antennular segment (see Marin, Sokolova, 2014: fig. $14 a-h)$.

The genetic divergence ( $p$-distances) of COI mtDNA gene marker between Xiphocaridinella dbari and other Caucasian Xiphocaridinella species correspond to characteristic interspecific values calculated for Decapoda and cave shrimps (Fig. 10; Table 1) (after Knowlton et al., 1993; Knowlton, Weigt, 1998; Hebert et al., 2003; Sites, Marshall, 2004; Zakšek et al., 2007, 2009; Lefébure et al., 2006a, b; Marin, 2017b, 2018a, b).

Order Amphipoda Latreille, 1816

Family Niphargidae Bousfield, 1977

Genus Niphargus Schiödte, 1849

Niphargus gegi sp.n.

Figs. $2 a, b, 3-7$.

MATERIAL EXAMINED. Holotype: 1 male (tl. $18.0 \mathrm{~mm}$ ), ZMMU Mb1147, Abkhazia, Gagry region, Bzyb River Canyon, Gegskaya Cave, $43^{\circ} 23^{\prime} 43.7^{\prime \prime} \mathrm{N} 40^{\circ} 27^{\prime} 28.4^{\prime \prime} \mathrm{E}$, about $273 \mathrm{~m}$ above sea level, in subterranean lake, coll. I. Marin, 17 Sept. 2017; 5 nonovigerous females, 5 males, (LEMMI), same locality and date as neotype. 1 female, 1 damaged specimen (LEMMI), Abkhazia, Gagry region, Reprua river, $43^{\circ} 19^{\prime} 52^{\prime \prime} \mathrm{N} 40^{\circ} 12^{\prime} 17.6^{\prime \prime} \mathrm{E}, 0-4 \mathrm{~m}$ above sea level, in river flow, coll. I. Marin \& S. Sinelnikov, 10 Aug. 2016.

DESCRIPTION. Body moderately slender. Head (Fig. 6a) large, vaulted, without rostrum and with subrounded lateral cephalic lobes and excavated antero-ventral sinus (Figs $2 c, d, 6 a$ ), eyes absent. Mesosomal and metasomal segments smooth, without specific features (Fig. $2 c, d$ ); coxae moderately large, with short ventro-marginal setae (Fig. 8f). Pereonites I-VI without setae; pereonites V-VII with 1-2 postero-ventral setae each. Pleonites I-III with several setae along postero-dorsal margin. Epimeral plate I with blunt postero-ventral corner (Fig. 8f). Epimeral plate II with ventral margins convex and blunt postero-ventral corner. Epimeral plate III ventral margin sinusoid postero-ventral corner triangular, distally. Urosomite I with one seta on each dorsolateral side, and with one postero-ventral spine near the basis of uropod I. Urosomites II-III unarmed. Coxal gills ovoid, of moderate size, never reaching the distal tip of pereiopod article 2 .

Antenna 1 (Fig. 6a) slender, overreaching half of the body (Fig. $2 c, d$ ); peduncular articles moderately slender, ratio: 1:1.3:1 (Fig. $6 a$ ); flagellum consisting of about 30 articles, most of them with two short aesthetascs each; accessory flagellum short, 2-articulated.

Antenna 2 (Fig. 6a) moderately slender, peduncular article 3 equal to article 2, both articles bearing long setae along ventral margin; flagellum relatively slender, consisting of 910 articles bearing relatively short setae (Fig. $6 a$ ).

Mouthparts. Labrum (Fig. 6b) entire, broader than long, with entire outer lobes and developed inner lobes exceeding half of the outer lobes. Mandibles (Figs $6 c, 9 b$ ) with incisor process and pars incisiva similar to other Niphargus species; mandibular palp with 3 articles: article 1 smooth; article 2 with numerous setae, article 3 subfalciform, equal to article 2, with numerous marginal and long distal setae, with several setae on the inner surface. Maxilla 1 (Fig. $6 d$ ) with: inner plate with 6 distal setae, outer plate with 7 spines armed with 1-2 small lateral teeth each (Fig. 9a); palp 2articulated, distal article with 9-10 simple setae distally. Maxilla 2 (Fig. 6e) with smooth well developed lobes armed with distolateral setae only. Maxilliped (Fig. 6f) with short inner plates, left plate with 8-10 distal simple spines; outer plate reaching the half of palp article 2, with a row of inner lateral spines; palp 4-articulated (Fig. 9e).

Gnathopods moderately large, with segment 6 slightly larger than corresponding coxae. Gnathopod 1 (Figs $7 a, c$; $9 f$ ) with article 2 long, about 3 times as long as wide, with long simple setae along the posterior and postero-distal margins; article 3 quadrate, as long as wide, similar to article 4; article 4 quadrate, about as long as wide, with a row of setae along posterior margin; article 5 triangular in shape, shorter than article 6; article 6 (propodus) large, nearly as long as broad, trapezoid, with 8 groups of posterior marginal setae; palmar margin poorly convex, slightly serrated, with medium simple setae, defined on the outer face by one strong corner spine accompanied laterally by 2 short serrate small spines (Fig. 9f); dactylus strong and sharp, not reaching the posterior margin of article 6 .

Gnathopod II (Fig. 7b, d) remarkably larger than gnathopod I; article 2 long, about 4 times as long as wide, with long simple setae along the posterior and postero-distal margins; article 3 quadrate, with one median group of setae along posterior margin; article 4 quadrate, about 1.5 times as long as wide, with a row of setae along postero-median margin; article 5 triangular in shape, shorter than article 6; article 6 (propodus) large, subtrapezoid, nearly as long as broad, with 6-8 groups of posterior marginal setae; palmar margin poorly convex, oblique almost $2 / 3$ of propodus length, with medium simple setae, defined on the outer face by one strong corner spine without accompanying smaller spines (Fig. 9g); dactylus strong and sharp, reaching the posterior margin of article 6 .

Ambulatory pereiopods slender, covered with clusters of short setae, characteristic for "Niphargus ablaskiri" species group. Pereiopods II (Fig. 8a) with slender poorly setose articles; article 2 about 7 times as long as wide, with the posterior margin bearing long marginal setae; articles 3 short, about as long as wide; article 4 about 4 times as long as wide, with small setae along dorsal and ventral margins; articles 5-6 almost equal, about 3-4 times as long as wide, with bunches of short spines along the ventral margin; dactylus stout, curved, sharp distally; outer margin of dactylus with one median short plumose seta.

Pereiopods IV (Fig. 8b) similar to pereiopod III, with slender poorly setose articles; article 2 about 7 times as long as wide, with the posterior margin bearing long marginal setae; articles 3 short, about as long as wide; article 4 about 4 times as long as wide, with small setae along dorsal and ventral margins; articles 5-6 almost equal, about 3-4 times as long as wide, with bunches of short spines along ventral margin; dactylus (Fig. $9 h$ ) stout, curved, sharp distally; outer margin of dactylus with one median short plumose seta. 


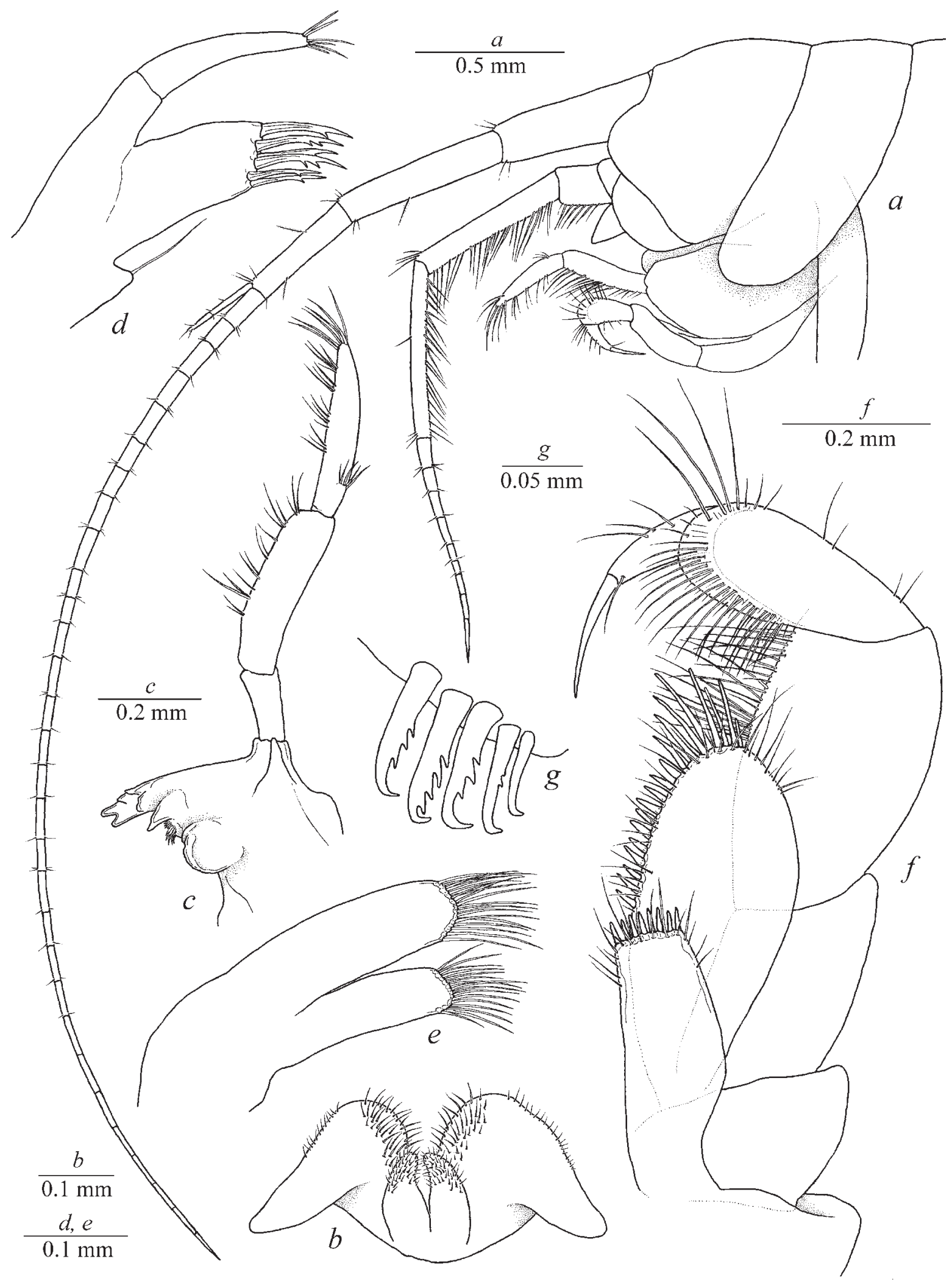

Fig. 6. Niphargus gegi sp.n., LEMMI, male, Gegskaya (Gega) Cave, Arabika karst massif: $a$ - head; $b-$ labrum; $c-$ mandible; $d$ maxilla I; $e$ - maxilla II; $f$ - maxilliped; g - setae of pleopod.

Рис. 6. Niphargus gegi sp.n., LEMMI, самец, Гегская пещера, карстовый массив Арабика: $a$ - голова, $b-$ верхняя губа (лабрум); $c$ - мандибула; $d-$ максилла I; $e$ - максилла II; $f$ - максиллипеда; $g$ - щетинки плеопод. 


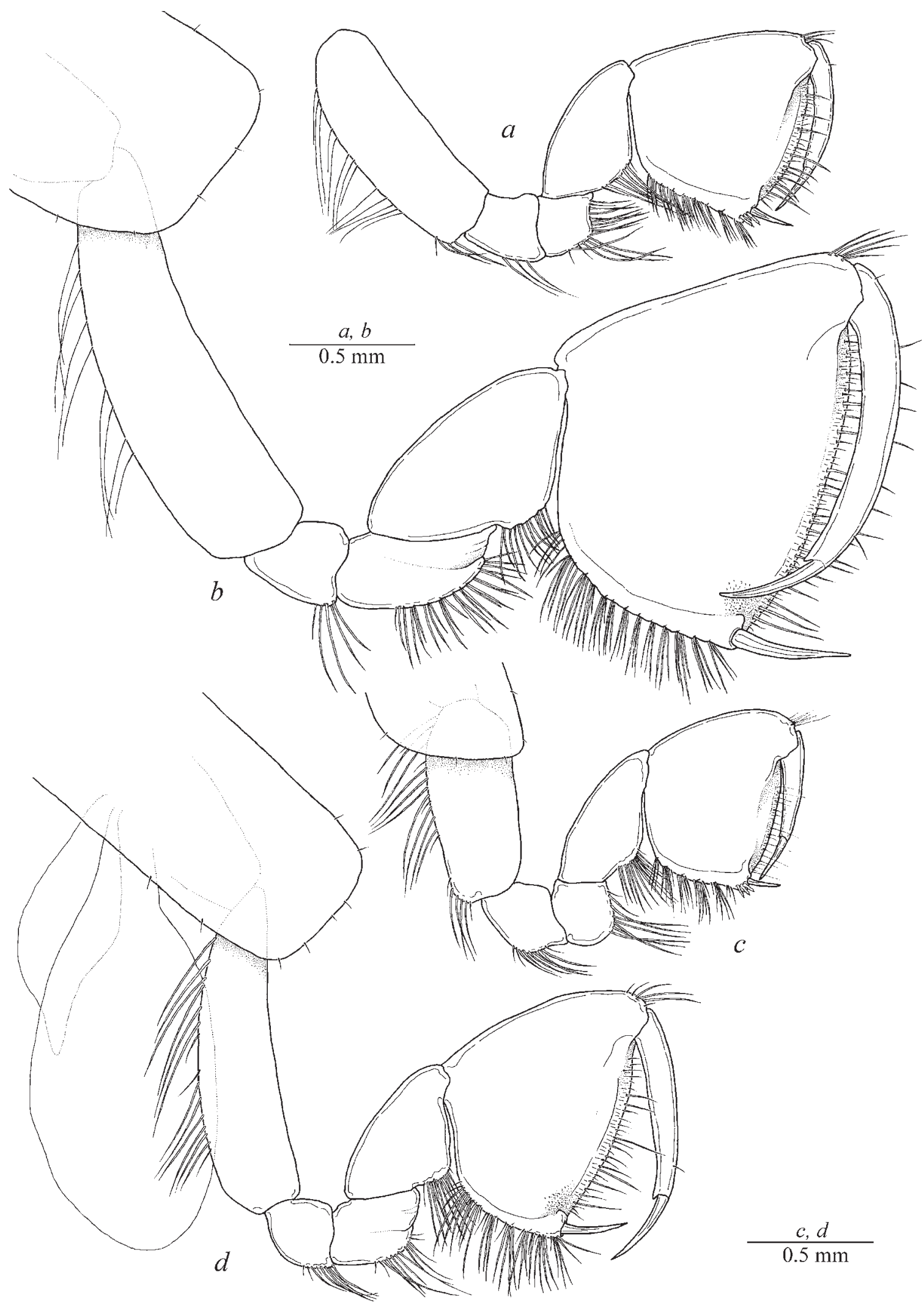

Fig. 7. Niphargus gegi sp.n., LEMMI, male $(a, b)$, female $(c, d)$, Gegskaya (Gega) Cave, Arabika karst massif: $a, c$ — gnathopod I, $b$, $d$ - gnathopod II.

Pис. 7. Niphargus gegi sp.n., LEMMI, самец $(a, b)$, самка $(c, d)$, Гегская пещера, карстовый массив Арабика: $a, c$ — гнатопода I; $b, d$ - гнатопода II. 
Pereiopod V (Fig. 8c) with article 2 subrectangular, widening proximally, with feebly marked ventro-posterior lobe, posterior margin barely concave in the middle, bearing a row of 9-10 posterior short marginal setae, anterior margin of article 2 is slightly convex, with a row of slender marginal setae that slightly longer than posterior; article 3 subquadrate, as long as wide; article 4 about 3 times as long as wide, with bunches of short spines along dorsal and ventral margins; article 5 slender, about 4 times as long as wide, slightly longer than article 3 and shorter than article 5; article 6 slender, about 4 times as long as wide, bunches of short spines; dactylus slender, with a tiny median spine at the inner margin and one short median setae at the outer margin.

Pereiopods VI-VII (Fig. 8d,e) almost similar, moderately slender, with article 2 narrow, slightly shorter twice as long as broad, without a distinct ventro-posterior lobe and with a concave posterior margin bearing a row of 10-11 short posterior marginal setae; anterior margin convex, with a row of longer marginal setae; articles 3 short, as long as wide; article 4 about 5 times as long as wide, with bunches of short spines along dorsal and ventral margins; article 5 slender, about 3 times as long as wide, slightly longer than article 3 and shorter than article 5, with bunches of spines intermixed with single short setae; article 6 slender, about 10-11 times as long as wide, bunches of short spines; dactylus (Fig. 9i) slender, with a tiny median spine at the inner margin and one short median setae at the outer margin.

Pleopods normal, without specific features, with 4 retinacles.

Uropod I with protopodite (peduncle) about 3.5 times as long as wide, slightly longer than rami, with a dorso-external and dorso-internal row of slender spines; rami straight and equal in length, both rami with lateral and distal slender spines (Fig. 8f). Uropod II with protopodite (peduncle) about 2.5-3 times as long as wide, slightly shorter than rami, inner ramus barely shorter than the outer one, both rami with lateral and distal slender spines. Uropod III (Figs $8 f, g, 9 j$ ) with protopodite about $1.5-2$ times as long as wide, rami unequal, inner ramus short bearing several small distal spines; outer ramus long, proximal article about 9-10 times as long as wide, about 4-5 times longer than distal article, distal article about 2 times as long as wide, both article armed with setae and clusters of small setae (Fig. 8f, $g$ ).

Telson (Figs $8 h, 9 c, d$ ) about 1.5 times as long as broad, ca $70 \%$ incised, lobes obtuse and rounded distally, bearing 3-4 long distal and 1-2 subdistal spines; without lateral seta; distal and subdistal spines reaching the half length of the telson.

COLORATION. Body, appendages and internal organs whitish or yellowish (Fig. $2 a, b$ ) characteristic to all stygobiotic representatives of the genus Niphargus.

BODY SIZE. The largest collected female has tbl. 18.0 $\mathrm{mm}$; the largest collected male has tbl. $16.0 \mathrm{~mm}$.

GENBANK ACCESSION NUMBER. MK875788.

DISTRIBUTION. The species is known from an underground lake inside the Gegskaya Cave, $43^{\circ} 23^{\prime} 43.7^{\prime \prime} \mathrm{N} 40^{\circ}$ 27'28.4"E, Abkhazia, Western Caucasus (the type locality). It can also be assumed (see Discussion) that the same species can live in underground lakes inside the Krubera-Voronya Cave as specimens differing from population from the Gegskaya Cave for about $12 \%$ by COI mtDNA gene marker (about 0.12 substitutions per 100 nucleotide positions $(n=2)$ ) were collected in a stream of the Reprua river (e.g. Kiknadze, 1979; Klimchouk, 1990, 2006). Moreover, the specimen differing by about $12 \%$ (about 0.12 substitutions per 100 nucleotide positions $(\mathrm{n}=1))$ was described by Sidorov [2014] from the Troika Cave $\left(43^{\circ} 23^{\prime} 00.0^{\prime \prime} \mathrm{N} 40^{\circ} 22^{\prime} 00.0^{\prime \prime} \mathrm{E}\right.$ ) (see Tab. 2; Figs. 1, 10; see below). It is possible that the same species also inhabit the underground lake inside the Verevkina Cave $\left(43^{\circ} 24^{\prime} 56.0^{\prime \prime} \mathrm{N} 40^{\circ} 21^{\prime} 23.0^{\prime \prime} \mathrm{E}\right)$ at a depth -400 $\mathrm{m}$ (Turbanov, pers. comm.).

ECOLOGY. Niphargus gegi sp.n. seems to be a lake dweller. All collected specimens were found in the underground lake and small pools inside the Gegskaya Cave. The specimens sampled in a stream of the Reprua river were dead and partly destroyed, being probably washed out of the Arabika karst massif system.

ETYMOLOGY. The species is named after the Gegskaya (Gega) Cave $\left(43^{\circ} 23^{\prime} 43.7^{\prime \prime} \mathrm{N} 40^{\circ} 27^{\prime} 28.4^{\prime \prime} \mathrm{E}\right)$, where it was firstly found.

TAXONOMIC REMARKS. The new species clearly belongs to the Caucasian "Niphargus ablaskiri" species group that is a part of the "carpathicus" group (after Straškraba, 1972), including Niphargus ablaskiri Birstein, 1940 and N. inermis Birstein, 1940 described from the Abrskil Cave $\left(42^{\circ}\right.$ $55^{\prime} 14.0^{\prime \prime} \mathrm{N} 41^{\circ} 33^{\prime} 17.0^{\prime \prime} \mathrm{E}$ ) and the Lower Shakuran (=NizhneShakuranskaya) Cave $\left(43^{\circ} 01^{\prime} 47.8^{\prime \prime} \mathrm{N}, 41^{\circ} 20^{\prime} 02.0^{\prime \prime} \mathrm{E}\right), N$. vadi$m i$ Birštein, 1961 from Crimean Peninsula, Iranian N. daniali Esmaeili-Rineh et Sari, 2013 and two European species, N. ambulator G. Karaman, 1975 and N. gebhardti Schellenberg, 1934 (Fig. 10; Table 2), respectively. Taxonomic features of the group are: 1) unequal gnathopods I and II; 2) different carpal segments (in form and shape) of pereiopods I and II; 3) elongated deeply dissected with long distal, subdistal and lateral long simple spines; 4) simple dactyli of pereiopod III-VII without ventral spines and 5) short distal article of uropod III [Birstein, 1940]. The new species has all these morphological features (Figs 6-9). The detected genetic differences (about 12\%) between specimens from the Gegskay Cave, the Troika Cave and the Reprua river (Table 2) may indicate the presence of several cryptic species inside these neighboring but isolated karst systems. However, the present-day genetic knowledge on the Caucasian Niphargus species is poor and insufficient for a more accurate taxonomic revision. Moreover, such a revision is beyond the scope of this study and will be performed later when additional genetic data became available.

The most morphologically similar and genetically close $N$. inermis, known from the Lower Shakuran (=NizhneShakuranskaya) Cave $\left(43^{\circ} 01^{\prime} 47.8^{\prime \prime} \mathrm{N}, 41^{\circ} 20^{\prime} 02.0^{\prime \prime} \mathrm{E}\right)$, can be reliably separated from Niphargus gegi by less numerous spines on telson with 3 distal spines on each lobe of the new species (Figs 8h, 9c,d) (vs. 5-6 distal spines on each lobe of telson in $N$. inermis [Birštein, 1940: fig. 3g]). The new species can be reliably differed from $N$. ablaskiri known from Abrskil Cave (Achkshe-Tyz-Gua Cave, 42 ${ }^{\circ} 55^{\prime} 14.0^{\prime \prime} \mathrm{N}$ $41^{\circ} 33^{\prime} 17.0^{\prime \prime} \mathrm{E}$ ), by morphological features of telson $-N$. ablaskiri has several lateral long simple spines and 5 distal spines on each lobe of telson (see Birstein, 1940: fig. 2f) vs. only 1 lateral and 3 distal spines on each lobe of telson in Niphargus gegi (Figs $8 h, 9 c, d$ ). Moreover, the genetic $p$ distances between the new species and the related Caucasian species, $N$. ablaskiri and $N$. inermis, exceed $15 \%(0.15$ substitutions per 100 nucleotide position) (Tab. 1; Fig. 10), which makes it possible to separate it as a valid biological species (see Hebert et al., 2003; Copilas-Ciocianu et al., 2017; Delić et al., 2017; Zakšek et al., 2019; see Discussion).

The new species can be separated from $N$. daniali, known from Danial cave $\left(36^{\circ} 39^{\prime} 51.2^{\prime \prime} \mathrm{N} 51^{\circ} 10^{\prime} 51.4^{\prime \prime} \mathrm{E}\right)$ in Iran, by 


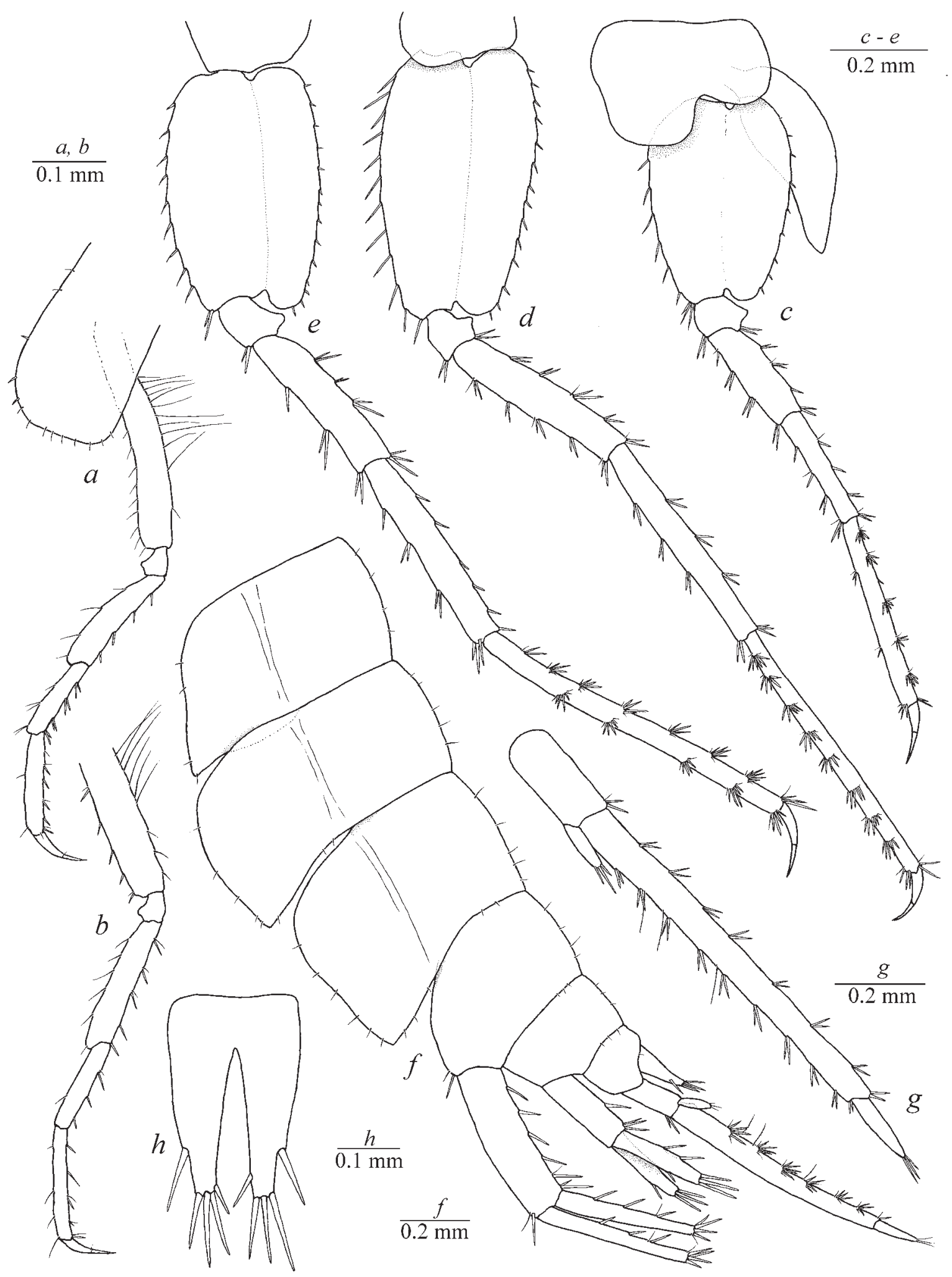

Fig. 8. Niphargus gegi sp.n., LEMMI, male, Gegskaya (Gega) Cave, Arabika karst massif: $a$ - pereiopod III; $b$ - pereiopod IV; $c-$ pereiopod V; $d$ - pereiopod VI; $e$ - pereiopod VII; $f$ - urosomites and uropods; $g$ - uropod $3 ; h$ - telson.

Pиc. 8. Niphargus gegi sp.n., LEMMI, самец, Гегская пещера, карстовый массив Арабика: $a$ - переопода III; $b$ - переопода IV; $c$ - переопода V; $d$ - переопода VI; $e$ - переопода VII; $f$ - уросомиты и уроподы; $g$ - уропода III; $h$ - тельсон. 


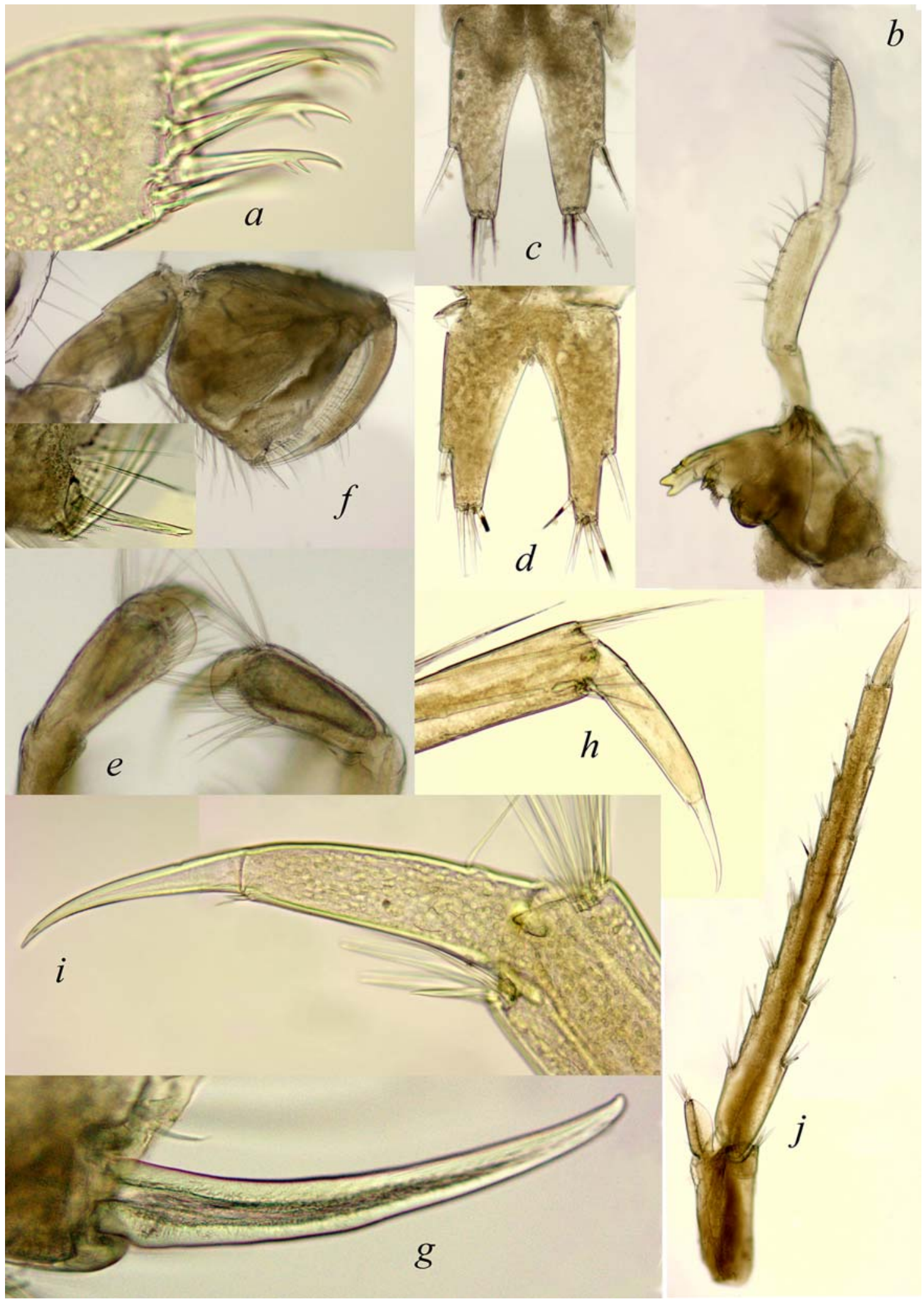

Fig. 9. Niphargus gegi sp.n., LEMMI, female $(a-f, i)$, male $(g, j)$, Gegskaya (Gega) Cave, Arabika karst massif: $a$ - outer plate of maxilla I; $b$ - mandible; $c, d$ - telson; $e$ - distal article of maxilliped; $f$ - gnathopod II; $g$ - corner palmar spine of gnathopod II; $h$ dactylus of pereiopod III; $i$ - dactylus of pereiopod 7; $j$ - uropod III.

Рис. 9. Niphargus gegi sp.n., LEMMI, самка $(a-f, i)$, самец $(g, j)$, Гегская пещера, карстовый массив Арабика: $a-$ наружная пластина максиллы I; $b$ - мандибула; $c, d$ - тельсон; $e$ - дистальная часть максиллипед; $f$ - гнатопода II; $g$ - угловой пальмарный шип гнатоподы II; $h$ - дактилус переоподы III; $i$ - дактил переопод VII; $j$ - уроподы III. 
Table 2. Pairwise interspecific genetic (COI mtDNA) distances ( $p$-distance \pm SE) between Niphargus gegi sp.n. from Gegskaya (Gega) Cave $(\mathrm{n}=3)$ and other Niphargus known from the Caucasus, Crimean Peninsula and neighboring area.

Таблица 2. Попарные межвидовые генетические (COI мтДНК) дистанции (p-distance $\pm \mathrm{SE}$ ) между Niphargus gegi sp.n. из Гегской пещеры $(\mathrm{n}=3)$ другими видами рода Niphargus с Кавказа, Крыма и близлежащих регионов.

Niphargus gegi sp.n. from Troika Cave, Caucasus ( $\mathrm{n}=1)$

(identified as "N. inermis" [after Sidorov, 2014])

$0.121 \pm 0.014$

Niphargus gegi sp.n. from Reprua, Caucasus ( $\mathrm{n}=2)$

$0.125 \pm 0.015$

Niphargus bihorensis (Europe)

$0.187 \pm 0.019$

Niphargus timavi (Italy)

$0.181 \pm 0.020$

Niphargus julius (Italy)

$0.185 \pm 0.020$

Niphargus daniali (Iran)

$0.196 \pm 0.020$

Niphargus gebhardti (Europe)

$0.202 \pm 0.021$

Niphargus inermis (Nizhne-Shakuranskaya Cave, Caucasus)

$0.213 \pm 0.025$

Niphargus ambulator (Europe)

$0.221 \pm 0.021$

Niphargus molnari (Europe)

$0,247 \pm 0,022$

Niphargus vadimi (Crimean Peninsula)

$0.212 \pm 0.020$

Niphargus tauricum (Crimean Peninsula)

$0.235 \pm 0.022$

Niphargus dimorphus (Crimean Peninsula)

$0.225 \pm 0.022$

the presence of a single strong corner spine without accompanying short spines (Fig. $9 g$ ) (vs. the presence on 2 accompanying spines in N. daniali [Esmaeili-Rineh, Sari, 2013: fig. 8C, D]; a more slender uropod III with article 2 about 7 8 times as long as wide in males (Figs $8 g, 9 j$ ) and about 5 times as long as wide in females (see Sidorov, 2014: fig. 20) (compared to robust uropod III with article 2 about 4 times as long as wide in N. daniali [Esmaeili-Rineh, Sari, 2013: fig. 10F]) and more slender telson armed with only 1 lateral spine (vs. cluster of several simple lateral spines in N. daniali [Esmaeili-Rineh, Sari, 2013: fig. 10G]).

In addition, the new species clearly differs from $N$. ambulator and N. gebhardti in the presence on 1 strong corner spine without accompanying smaller spines (Fig. 9g) (vs. the presence on 2-3 accompanying small spines in both males and females in N. gebhardti [Angyal et al., 2015: fig. 13] and N. ambulator [Karaman, 1975: fig. 9F]; similar uropod III with short distal article (Figs $8 g, 9 j$ ) in both males and females (vs. longer distal segment in males in N. gebhardti [Angyal et al., 2015: fig. 16] and N. ambulator [Karaman, 1975: fig. 7H, I] and telson only 1 lateral spine (Figs $8 h, 9 c, d)$ (vs. 2 pairs in N. gebhardti [Angyal et al., 2015: fig. 16] and N. ambulator [Karaman, 1975: fig. 8D, I]. The species are geographically isolated as $N$. gebhardti is de-

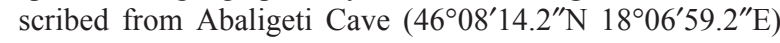
in Hungary and N. ambulator is recorded from the Province of Como in Italy. Genetic difference of the new species from $N$. gebhardti and $N$. ambulator by COI mtDNA gene marker is more than $20 \%$ (see Tab. 2) as well as $p$-distances between Niphargus gegi and other neighboring Niphargus species is more than $15 \%$ ( 0.15 substitutions per 100 nucleotide positions), which allow separating it as a distinct biological species (see Tab. 1; Fig. 10) (e.g. Copilas-Ciocianu et al., 2017; Delić et al., 2017; Zakšek et al., 2019).

\section{Discussion}

The atyid shrimp genus Xiphocaridinella Sadowsky, 1930 (Crustacea: Decapoda: Atyidae) currently includes 8 valid species described in the stygobiotic habitats of the Caucasus (e.g. Sadowsky, 1930; Birstein, 1939, 1948; Juzbaš'jan, 1940; Marin, Sokolova, 2014; Marin, $2017 \mathrm{a}, \mathrm{b}, 2018 \mathrm{a}, \mathrm{b})$. The present study increases the number up to 9 species while the real diversity of the genus is possibly richer and comparable to the combined diversity of relative Dinaric stygobiotic genera Troglocaris Dormitzer, 1853 and Spelaeocaris Matjašiè, 1956. At the same time, the morphological similarity of the Caucasian representatives of the genera Xiphocaridinella and Niphargus creates a number of taxonomic problems with intra- and interspecific delimitation. Thus, additional non-morphological information, i.e., geographic origin and distribution of the species, sequences of gene markers, is usually used for the species identification. For example, Marin [2017a, b, 2018a, b] mentioned that all known Caucasian

Xiphocaridinella species are strictly restricted to certain karst cave ecosystem, showing a genetic divergence of at least $5 \%$ (COI mtDNA), allowing to describe them as separate species [after Lefébure et al., 2006a, b]. However, these estimates are essentially approximate. The species delimitation within subterranean crustacean "lake dwellers" is probably correlated due to salting and changes of the sea level and the following events in geological history (e.g. Delić et al., 2017; Guy-Haim et al., 2018). The time of the origin of 

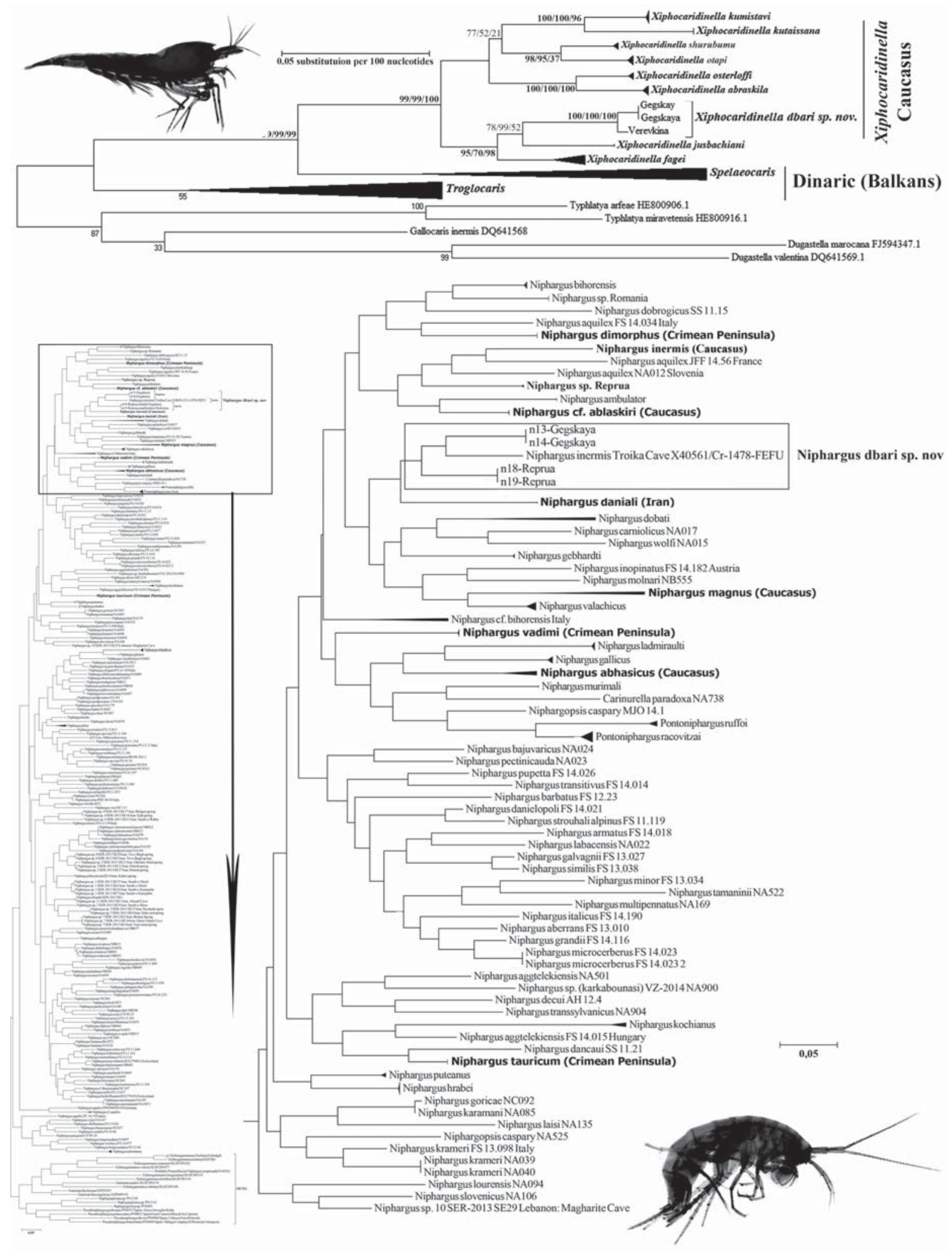

Fig. 10. Phylogenetic reconstruction (COI mtDNA gene marker) of studied Western Caucasian Xiphocaridinella (upper with BA/ML/ NJ algorithms) and Niphargus (lower) species (ML algorithm). The clade of related taxa is enlarged for Niphargus (lower right).

Рис. 10. Филогенетическая реконструкция (на основе генного маркера COI мтДНК) изученных видов западно-кавказских видов родов Xiphocaridinella (сверху, с помощью алгоритмов BA/ML/NJ) и Niphargus (снизу, ML алгоритм). Клада родственных таксонов увеличена для Niphargus (внизу справа). 
some subterranean lake-dwelling Niphargus lineages (e.g. Delić et al., 2017) and the genera splits in Troglocaris-like cave shrimps coincide with the period of the Dinaric orogenesis and salting of the Mediterranean basis (10-23MYA) [Popov et al., 2004; Sket, Zakšek, 2008] similar to the major epigean Gammarus species diversifications [Hou et al., 2011, 2014; Copilaş-Ciocianu, Petrusek, 2015, 2016; Mamos et al., 2016]. Besides, the splitting of species within Xiphocaridinella, Spelaeocaris and Troglocaris is probably correlated with the Messinian salinity crisis (5.96-5.33 MYA) and the Pleistocene glacial maxima (or the Quaternary glaciation) (2MYA-10.000YA) [Colantoni et al., 1979; Gargani, Rigollet, 2007; Garcia-Castellanos et al., 2009], when the process of isolation of cave shrimp lineages within the certain karst systems occurred, which enabled them to survive in previously flooded caves.

Data on "molecular clocks" used in Troglocarislike cave shrimps, including Caucasian Xiphocaridinel$l a$, as a sequence (COI mtDNA) divergence rate about 1.4-2.4\% of substitutions per site on 1MYA [Knowlton et al., 1993; Knowlton, Weigt, 1998; Zakšek et al., 2007; Jugovic et al., 2012] calculating the splitting time within the Caucasian lineages/species from $~ 2.0$ to $10.0 \mathrm{MYA}$ ) (see Marin, 2017b; Table 1). Using known data, it is possible to assume two separate divergence events within Dinaric-Caucasian Xiphocaridinella lineages (genera) occurred about 9-15MYA (ancestor of Troglocaris separated from Spelaeocaris-Xiphocaridinella) and about 8-13MYA (ancestor taxon diverged for Dinaric Spelaeocaris and Caucasian Xiphocaridinella [Marin, 2017b]). It is difficult to compare this time with any geological events, and the divergence rates should be revised upwards in the percentage of substitutions by 1MYA [Marin, in prep.].

At the same time, similar genetic criteria for the species delimitation were never determined for the Caucasian representatives of the genus Niphargus. Modern molecular studies have shown that many widely distributed species of the genus Niphargus include a number of almost morphologically identical, but genetically different species, so called "cryptic species" [Lefébure et al., 2006a, b, 2007; Väinölä et al., 2008; Trontelj et al., 2009; Meleg et al., 2013; McInnery et al., 2014; Fišer et al., 2018]. Uncovering cryptic diversity is important for understanding species distribution, the levels of endemism and ecology (e.g. Oliver, 2011). The minimum $p$-distances (COI mtDNA) between Niphargus species deposited in GenBank (NCBI) is about 0.009 substitutions per 100 nucleotide positions in Niphargus gabrovceci S. Karaman, 1952 vs. Niphargus novomestanus S. Karaman, 1952 probably representing one species. The maximal is about $0.310 \mathrm{sub}-$ stitutions per 100 nucleotide positions (e.g. Niphargus gegi sp.n. vs. Niphargus kochianus). At the same time, the total average $p$-distance $( \pm \mathrm{SE})$ (COI mtDNA) between data on $200+$ species of the genus presented in GenBank (NCBI) is calculated as $0.214 \pm 0.016$ substitutions per 100 nucleotide positions. Genetic p-dis- tances with other genera slightly exceed the total overall average between species within the genus: $0.307 \pm$ 0.021 with the genus Echinogammarus Stebbing, 1899 (Gammaridae), $0.296 \pm 0.023$ with the genus Haploginglymus Mateus et Mateus, 1958 (Niphargidae) and $0.256 \pm 0.025$ with the genus Gammarus Fabricius, 1775 (Gammaridae) (own calculations).

With regard to the genus Niphargus, the attempts to determine the genetic delimitation threshold, including cryptic species, had already been made. For example, Švara et al. [2015] identified a genetic distance between Croatian $N$. zagorae and $N$. boskovici at about $14 \%$, which is presumably close to the reproductive barrier found in interbreeding experiments [Cothran et al., 2013; Lagrue et al., 2014]. At the same time, the morphological differences between these species are insignificant and are determined only by the setal ornamentation on urosomite III and pereiopods III-IV as well as the different proportions in gnathopods II and pereiopods V-VII [Švara et al., 2015]. Recent molecular genetic studies suggest that most of Niphargus species have a limited distribution, being mostly narrow endemics [Fišer et al., 2008; Delić et al., 2017], while widespread taxa are complexes of cryptic species even for epigean species [Lefébure et al., 2006, 2007; Deliæ et al., 2017]. Deli et al. [2017] used a threshold value of 0.16 substitutions per site to separate species within "Niphargus arbiter - Niphargus salonitanus" species complex, belonging to "lake giants" from the Dinaric Karst, where all species overlap significantly in morphology and cannot be uniquely separated without help molecular markers. This most conservative 0.16-threshold (patristic distances) approach is confirmed by other researches (after Lefébure et al., 2006a). Lefébure et $a l$. [2006b] found that $95 \%$ of the observed intraspecific divergences in the studied population of Niphargus virei Chevreux, 1896 were below 0.2 substitutions per site, and that the 0.16-threshold could be used to differentiate inter- from intraspecific distances with reasonable success (about $87 \%$ of success on the entire data set and $99 \%$ of success when cryptic species and a peculiar genus were removed).

Thus, it is possible to assume a threshold of 0.15 substitutions per site for delimitation of the species within the Caucasian Niphargus ablaskiri species complex from neighboring caves of the Arabika karst massif and other relative Caucasian species (see Table 2), that is even rather conservative according to recent investigations [Copilaş-Ciocianu et al., 2017; Delić et al., 2017; Zakšek et al., 2019]. This threshold also makes it possible to separate species using the characteristics of their geographical distribution and the possible connection between adjacent karst massifs. Although, divergence rates need to be corrected in the future using additional genetic data obtained for the Caucasian niphargids.

Molecular clock calibration for peracarid crustaceans for COI mtDNA gene marker was proposed to be $1.25 \%$ of substitutions per $1 \mathrm{MYA}$ by Ketmaier et al. 
[2003] and 0.34 to $0.76 \%$ of substitutions per $1 \mathrm{MYA}$ according to Lefébure et al. [2006b] (see review in Gay-Haim et al., 2018). The splitting time calculated for Xiphocaridinella and Troglocaris-like shrimps from the same karst systems exceed the time of splitting between the Caucasian Niphargus lineages by at least for 2-3 times and also need to be studied using new genetic data and other gene markers. At the same time, nuclear genomics (single nucleotide polymorphism and microsatellites) should also be used to analyze the restriction of gene flow, in order to confirm the species isolation, since the allopatric speciation in the hypogeal aquatic fauna under different effective populations can also be associated with several evolutionary molecular genetic processes.

Acknowledgements. Author is very thankful to Dr. Roman Dbar (Institute of Ecology of the Academy of Sciences of Abkhazia), Anastasia Ashepkova (A.N. Severtzov Institute of Ecology and Evolution of RAS) and Sergey Sinelnikov (I.D. Papanin Institute of Inland Waters of RAS) for the help during the sampling as well as to Ilya Turbanov (I.D. Papanin Institute of Inland Waters of RAS), Natalia and Andrey Sizikov for the providing of additional specimens from the Verevkina Cave. Special thanks are sending to Dr. Boris Sket (University of Ljubljana), Dr. Vassily A. Spiridonov (P.P. Shirshov Institute of Oceanology of RAS) and an anonymous reviewer for valuable comments and remarks to the manuscript.

\section{References}

Angyal D., Balázs G., Zakšek V., Krízsik V., Fišer C. 2015. Redescription of two subterranean amphipods Niphargus molnari Méhely, 1927 and Niphargus gebhardti Schellenberg, 1934 (Amphipoda, Niphargidae) and their phylogenetic position // ZooKeys. Vol.509. P.53-85. https://doi.org/10.3897/zookeys. 509.9820

Anonymous. 2018. Gegskaya Peschera [Gegskay Cave] // Peschery Mira [Caves of the World], Internet Resource, http://pescherimira.ru/karstovie-peshcheri/115-gegskaya-peshchera.html[in Russian] (last access 20/03/2019).

Behrmann-Godel J., Nolte A.W., Kreiselmaier J., Berka R., Freyhof J. 2017. The first European cave fish // Current Biology. Vol.27. No.7. P.257-258. https://doi.org/10.1016/ j.cub.2017.02.048

Birstein J.A. 1939. O peshernysh krevetkah Abhazii [About cave shrimps of Abkhazia] // Zoologichesky Zhurnal. Vol.18. P.960974 [in Russian].

Birstein J.A. 1940. [Über die Fauna der Höhlen Amphipoden Abchasiens] // Byulleten Moskovskovo Obshchestva Ispytatelei Prirody. Otdel biologicheskiy. Vol.49. P.47-55 [in Russian with German abstract].

Borowsky R. 2018. Cavefishes // Current Biology Vol.28. No.2. P.60-64. https://doi.org/10.1016/j.cub.2017.12.011

Colantoni P., Gallignani P., Lenaz R. 1979. Late Pleistocene and Holocene evolution of the North Adriatic continental shelf (Italy) // Marine Geology. Vol.33. P.41-50.

Copilaş-Ciocianu D., Petrusek A. 2015. The southwestern Carpathians as an ancient centre of diversity of freshwater gammarid amphipods: Insights from the Gammarus fossarum species complex // Molecular Ecology. Vol.24. P.3980-3992. https://doi.org/10.1111/mec.13286

Copilaş-Ciocianu D., Petrusek A. 2016. Phylogeography of a freshwater crustacean species complex reflects a long- gone archipelago // Journal of Biogeography. Vol.44. P.421-432. https:// doi.org/10.1111/jbi.12853
Copilaș-Ciocianu D., Fišer C., Borza P., Balázs G., Angyal D., Petrusek A. 2017. Low intraspecific genetic divergence and weak niche differentiation despite wide ranges and extensive sympatry in two epigean Niphargus species (Crustacea: Amphipoda) // Zoological Journal of the Linnean Society. Vol.20. P.1-15. https://doi.org/10.1093/zoolinnean/zlw031

Cothran R.D., Stiff A.R., Chapman K., Wellborn G.A., Relyea R.A. 2013. Reproductive interference via interspecific pairing in an amphipod species complex // Behavioral Ecology and Sociobiology. Vol.67. P.1357-1367. https://doi.org/10.1007/ s00265-013-1564-z

Culver D.C., Pipan T. 2009. The biology of caves and other subterranean habitats. Oxford, UK: Oxford University Press.

Delić T., Švara V., Coleman C.O., Trontelj P., Fišer C. 2017. The giant cryptic amphipod species of the subterranean genus Niphargus (Crustacea, Amphipoda) // Zoologica Scripta. https://doi.org/10.1111/zsc. 12252

Delić T., Trontelji P., Rendos M., Fišer C. 2017. The importance of naming cryptic species and the conservation of endemic subterranean amphipods // Scientific Reports. Vol.7. No.1. P.3391. https://doi.org/10.1038/s41598-017-02938-z

Esmaeili-Rineh S., Sari A. 2013. Two new species of Niphargus Schiödte, 1849 (Crustacea: Amphipoda: Niphargidae) from two caves in Iran // Journal of Natural History. Vol.47. P.26492669. https://doi.org/10.1080/00222933.2013.802041

Fišer C., Robinson C.T., Malard F. 2018. Cryptic species as a window into the paradigm shift of the species concept // Molecular Ecology. Vol.27. No.3. P.613-635. https://doi.org/ $10.1111 / \mathrm{mec} .14486$

Garcia-Castellanos D., Estrada F., Jiménez-Munt I., Gorini C., Fernàndez M., Vergés J., De Vicente R. 2009. Catastrophic flood of the Mediterranean after the Messinian salinity crisis // Nature. Vol.462. P.778-78. https://doi.org/10.1038/nature08555

Gargani J., Rigollet C. 2007. Mediterranean sea level variations during the Messinian salinity crisis // Geophysical Research Letters. Vol.34. P.1-5. https://doi.org/10.1029/2007GL029885

Guy-Haim T., Simon-Blecher N., Frumkin A., Naaman I., Achituv Y. 2018. Multiple transgressions and slow evolution shape the phylogeographic pattern of the blind cave-dwelling shrimp Typhlocaris // PeerJ. Vol.6. e5268. https://doi.org/10.7717/ peerj. 5268

Hebert P.D.N., Cywinska A., Ball S.L., De Waard J.R. 2003. Biological identifications through DNA barcodes // Proceedings of the Royal Society of London. Series B. Vol.270. P.313-322. https://doi.org/10.1098/rspb.2002.2218

Hou, Z., Sket B., Fišer C., Li S. 2011. Eocene habitat shift from saline to freshwater promoted Tethyan amphipod diversification // PNAS. Vol.108. No.35. P.14533-14538. https://doi.org/ $10.1073 /$ pnas. 1104636108

Hou Z., Sket B., Li S. 2014. Phylogenetic analyses of Gammaridae crustacean reveal different diversification patterns among sister lineages in the Tethyan region // Cladistics. Vol.30. P.352365. https://doi.org/10.1111/cla.12055

Jeffery W.R. 2001. Cavefish as a model system in evolutionary developmental biology // Developmental Biology. Vol.231. P.1-12. https://doi.org/10.1006/dbio.2000.0121

Jugovic J., Jalžić B., Prevorčnik S., Sket B. 2012. Cave shrimps Troglocaris s. str. (Dormitzer, 1853), taxonomic revision and description of new taxa after phylogenetic and morphometric studies // Zootaxa. Vol.3421. P.1-31.

Juzbaš'jan S.M. 1940. [On Shakuran cave shrimp] // Trudy biologicheskoi stantsii Narkomprosa Gruzinskoi SSR. Vol.1. P.7386 [in Russian].

Karaman G.S. 1975. 73. Contribution to the knowledge of the Amphipoda. Three Niphargus species from Yugoslavia and Italy, N. ambulator $\mathrm{n}$. sp. N. pupetta (Sket) and N. transitivus Sket (Fam. Gammaridae) // Poljoprivreda i Sumarstvo, Titograd. Vol.21. P.13-34.

Ketmaier V., Argano R., Caccone A. 2003. Phylogeography and molecular rates of subterranean aquatic Stenasellid isopods with a peri-Tyrrhenian distribution // Molecular Ecology. Vol.12. P.547-555. https://doi.org/10.1046/j.1365-294X.2003. 01734.x 
Kiknadze T.Z. 1979. [Geology, Hydrogeology and activity of limestone karst]. Tbilisi: Metzniereba. 232 pp. [In Russian]

Klimchouk A.B. 1990. [Karst circulation systems of the Arabika massif] // Peschery [Caves]. Perm University. P.6-16 [in Russian].

Klimchouk A.B. 2006. [The deepest cave in the world in the Arabika Massif and the evolution of the Black Sea] // Svet (The Light), Kiev. Vol.2. No.31. P.33-36 [in Russian].

Knowlton N., Weigt L.A. 1998. New dates and new rates for divergence across the Isthmus of Panama // Proceedings of the Royal Society of London. Series B. Vol.265. P.2257-2263. https://doi.org/10.1098/rspb.1998.0568

Knowlton N., Weigt L.A., Solorzano L.A., Mills D.K., Bermingham E. 1993. Divergence in proteins, mitochondrial DNA and reproductive compatibility across the Isthmus of Panama // Science. Vol.260. P.1629-1632.

Lagrue C., Wattier R., Galipaud M., Gauthey Z., Rullman J.P., Dubreuil C., Rigaud T., Bollache L. 2014. Confrontation of cryptic diversity and mate discrimination within Gammarus pulex and Gammarus fossarum species complexes // Freshwater Biology. Vol.59. P.2555-2570. https://doi.org/10.1111/ fwb. 12453

Lefébure T., Douady C.J., Gouy M., Gibert J. 2006a. Relationships between morphological taxonomy and molecular divergence within Crustacea: proposal of a molecular threshold to help species delimitation // Molecular Phylogenetics and Evolution. Vol.40. No.2. P.435-447. https://doi.org/10.1016/j.ympev. 2006.03 .014

Lefébure T., Douady C.J., Gouy M., Trontelj P., Briolay J., Gibert J. 2006b. Phylogeography of a subterranean amphipod reveals cryptic diversity and dynamic evolution in extreme environments // Molecular Ecology. Vol.15. P.1797-806. https:// doi.org/10.1111/j.1365-294X.2006.02888.x

Lefébure T., Douady C.J., Malard F., Gibert J. 2007. Testing dispersal and cryptic diversity in a widely distributed groundwater amphipod (Niphargus rhenorhodanensis) // Molecular Phylogenetics and Evolution. Vol.42. P.676-686. https://doi.org/ 10.1016/j.ympev.2006.08.020

Mamos T., Wattier R., Burzyñski A., Grabowski M. 2016. The legacy of a vanished sea: A high level of diversification within a European freshwater amphipod species complex driven by 15 My of Paratethys regression // Molecular Ecology. Vol.25. P.795-810. https://doi.org/10.1111/mec. 13499

Marin I.N. 2013. [Atlas of Decapod Crustaceans of Russia]. Moscow: KMK Scientific Press. 145 pp. [In Russian]

Marin I. 2017a. Troglocaris (Xiphocaridinella) kumistavi sp. nov., a new species of stygobiotic atyid shrimp (Crustacea: Decapoda: Atyidae) from Kumistavi Cave, Imereti, Western Georgia Caucasus // Zootaxa. Vol.4311. No.4. P.576-588. https:// doi.org/10.11646/zootaxa.4311.4.9

Marin I.N. 2017b. COXI based phylogenetic analysis of Caucasian clade of European Troglocaris s.l. (Crustacea: Decapoda: Atyidae) with the suggestion of a new taxonomic group structure // Biosystems Diversity. Vol.25. No.4. P.323-327. https://doi.org/ 10.15421/011749

Marin I. 2018a. Cryptic diversity of stygobiotic shrimp genus Xiphocaridinella Sadowsky, 1930 (Crustacea: Decapoda: Atyidae): the first case of species co-occurrence in the same cave system in the Western Caucasus // Zootaxa. Vol.4441. No.2. P.201-224. https://doi.org/10.11646/zootaxa.4441.2.1

Marin I. 2018b. Xiphocaridinella shurubumu Marin sp. n. (Crustacea: Decapoda: Atyidae) - a new stygobiotic atyid shrimp species from Shurubumu and Mukhuri caves, Chkhorotsku, Western Georgia, Caucasus // Zoologichesky Zhurnal. Vol.97. No.10. P.1238-1256. https://doi.org/10.1134/S0044513418100082

Marin I., Sokolova A. 2014. Redescription of the stygobiotic shrimp Troglocaris (Xiphocaridinella) jusbaschjani Birštein, 1948 (Decapoda: Caridea: Atyidae) from Agura River, Sochi, Russia, with remarks on other representatives of the genus from Caucasus // Zootaxa. Vol.3754. No.3. P.277-298. https://doi. org/10.11646/zootaxa.3754.3.3

McInerney C.E., Maurice L., Robertson A.L., Knight L.R.F.D., Arnscheidt J., Venditti C., Dooley J.S.G, Mathers T., Matthijs
S., Eriksson K., Proudlove G.S., Hänfling B. 2014. The ancient Britons: Groundwater fauna survived extreme climate change over tens of millions of years across NW Europe // Molecular Ecology. Vol.23. P.1153-1166. https://doi.org/ $10.1111 / \mathrm{mec} .12664$

Meleg I.N., Zakšek V., Fišer C., Kelemen B.S., Moldovan O.T. 2013. Can environment predict cryptic diversity? The case of Niphargus inhabiting Western Carpathian groundwater // PLoS ONE. Vol.8. e76760. https://doi.org/10.1371/journal. pone. 0076760

Parin N.V. 1983. [Noemacheilus (Troglocobitis) starostini sp. n. (Osteichthyes, Cobitidae) a new blind fish from subterranean waters of Kugitangtau (Turkmenia)] // Zoologichesky Zhurnal. Vol.62. P.83-89 [in Russian].

Romero A. 2001. The Biology of Hypogean Fishes. Dordrecht: Kluwer.

Romero A., Paulson K.M. 2001. It's a wonderful hypogean life: a guide to the troglomorphic fishes of the world // Environmental Biology of Fishes. Vol.62. P.13-41. https://doi.org/10.1023/ A:1011844404235

Sadowsky A.A. 1930. [Xiphocaridinella kutaissiana nov. gen. et sp. (fam. Atyidae) from subterranean cave near Kutaisi] // Zakavkazskiy kraevedcheskiy sbornik. Ser.A. Estestvoznanie. Tiflis. Vol.1. P.93-104 [in Russian].

Samokhin G., Bizyukin A.2018. Voronya Cave: Diving deeper into the deepest Cave on Earth // http://www.xray-mag.com/content/voronya-cave-diving-deeper-deepest-cave-earth [last access 20.03.2019].

Sendra A., Reboleira A.S.P.S. 2012. The world's deepest subterranean community - Krubera-Voronya Cave (Western Caucasus) // International Journal of Speleology. Vol.41. No.2. P.221230. https://doi.org/10.5038/1827-806x.41.2.9

Sidorov A.D. 2014. Towards the systematics of the subterranean amphipod genus Niphargus (Crustacea: Amphipoda: Niphargidae) of Transcaucasia: new records of $N$. inermis and $N$. iniochus in Abkhazia // Arthropoda Selecta. Vol.23. No.4. P.363-377.

Sidorov D., Taylor S.J., Sharina S., Gontcharov A. 2018. Zenkevitchiidae fam. nov. (Crustacea: Gammaroidea), with description of new subterranean amphipods from extremely deep cave habitats // Journal of Natural History. Vol.52. No.23-24. P.1509-1535. https://doi.org/10.1080/00222933.2018.1482017

Sidorov D.A., Gontcharov A.A., Sharina S.N. 2015. A new genus and two new species of cavernicolous amphipods (Crustacea: Typhlogammaridae) from the Western Caucasus // European Journal of Taxonomy. Vol.168. P.1-32. https://doi.org/10.5852/ ejt. 2015.168

Sidorov D.A., Samokhin G.V. 2016. Kruberia abchasica, a new genus and species of troglobiont amphipods (Crustacea: Gammaridae) from Krubera Cave (Western Transcaucasia) // Arthropoda Selecta. Vol.25. P.373-379.

Sites J.W., Marshall J.C. 2004. Operational criteria for delimiting species // Annual Review of Ecology, Evolution and Systematics. Vol.35. P.199-227.

Straškraba M. 1972. Les groupments des espèces du genre Niphargus (sensu lato) // Ruffo S. (ed.). Acets du Ier Colloque Internationale sur le genre Niphargus. Museo Civico di Storia Naturale di Verona, Verona. P.85-90.

Švara V., Delić T., Rađa T., Fišer C. 2015. Molecular phylogeny of Niphargus boskovici (Crustacea: Amphipoda) reveals a new species from epikarst // Zootaxa. Vol.3994. No.3. P.354-376. https://doi.org/10.11646/zootaxa.3994.3.2

Trontelj P., Douady C.J., Fišer C., Gibert J., Gorički Š., Lefébure T., Sket B., Zakšek V. 2009. A molecular test for cryptic diversity in ground water: How large are the ranges of macrostygobionts? // Freshwater Biology. Vol.54. P.727-744. https:/ /doi.org/10.1111/j.1365-2427.2007.01877.x

Väinölä R., Witt J.D.S., Grabowski M., Bradbury J.H., Jadzewski K., Sket B. 2008. Global diversity of amphipods (Amphipoda; Crustacea) in freshwater // Hydrobiologia. Vol.595. P.241255. https://doi.org/10.1007/s10750-007-9020-6

Zakšek V., Sket B., Trontelj P. 2007. Phylogeny of the cave shrimp Troglocaris: evidence of a young connection between Balkans 
and Caucasus // Molecular Phylogenetics and Evolution. Vol.42. P.223-235. https://doi.org/10.1016/j.ympev.2006.07.009 Zakšek V., Sket B., Gottstein S., Franjević D., Trontelj P. 2009. The limits of cryptic diversity in groundwater: phylogeography of the cave shrimp Troglocaris anophthalmus (Crustacea: Decapoda: Atyidae) // Molecular Ecology. Vol.18. No.5. P.931946. https://doi.org/10.1111/j.1365-294X.2008.04061.x
Zakšek V., Delić T., Fišer C., Jalžić B., Trontelj P. 2019. Emergence of sympatry in a radiation of subterranean amphipods // Journal of Biogeography, EarlyView. https://doi.org/10.1111/ jbi. 13514

Appendix 1. The list of nucleotide sequences of genera Xiphocaridinella, Troglocaris and Niphargus, used for molecular-genetic analysis.

Приложение 1. Список нуклеотидных последовательностей родов Xiphocaridinella, Troglocaris и Niphargus, используемых для молекулярно-генетического анализа.

\author{
Species \\ Xiphocaridinella dbari sp.n. from the \\ Gegskaya (Gega) Cave, Abkhazia, Western \\ Caucasus \\ Xiphocaridinella kutaissiana \\ Xiphocaridinella kumistavi \\ Troglocaris anophthalmus \\ Niphargus gegi sp.n. from the Gegskaya \\ (Gega) Cave, Abkhazia, Western Caucasus \\ Niphargus gegi sp.n. from Troika Cave, \\ Caucasus (as Niphargus inermis voucher \\ X40561/Cr-1478-FEFU) \\ Niphargus daniali \\ (Niphargus sp. 12 SER-2013 isolate SE28) \\ Niphargus dimorphopus \\ Niphargus vadimi \\ Niphargus tauricus \\ Niphargus bihorensis \\ Niphargus timavi \\ Niphargus julius \\ Niphargus gebhardti \\ Niphargus ambulator \\ Niphargus molnari
}

\author{
GenBank (NCBI) reference \\ MK875787 \\ MF287657, MF287655, MF287656 \\ MF287654, MF287652, MF287653 \\ FJ426022 \\ MK875788
}

KJ415376

KF581080

KX379138

KR905817

KR905823

KY706873, KY706930, KF218661-KF218666

KY706810

KY706723, KY706739, KY706780, KY706914,

KY706943

KP967553, KP967554, KY706947

KX379125, KY706884, KY706897

KP967552, KY643567 